\title{
Titanium Dioxide Nanoparticles Mitigated 2,4,6- Trinitrobenzenesulfonic (TNBS) Acid Solution Induced Colitis By Downregulating NF-kB Related Transcription
}

\section{Yanjun Gao}

Peking University

Shumin Duan

Peking University

Lizhi Lyu

Peking University

Weixing Xu

Peking University

Xiaxian Ou

Peking University

Lin Xu

Peking University

Yun Wang ( $\nabla$ wangyun@bjmu.edu.cn )

Peking University https://orcid.org/0000-0002-4720-636X

\section{Research}

Keywords: Titanium dioxide, Nanoparticles, Colitis, oxidative stress, NF-KB signal pathway

Posted Date: December 6th, 2021

DOI: https://doi.org/10.21203/rs.3.rs-1073233/v1

License: (c) (1) This work is licensed under a Creative Commons Attribution 4.0 International License. Read Full License 


\section{Abstract}

\section{Background}

Titanium dioxide $\left(\mathrm{TiO}_{2}\right)$ with nanofractions is increasingly applied in food products as a food additive, which makes consumers under the health risks of titanium dioxide nanoparticles $\left(\mathrm{TiO}_{2}-\mathrm{NPs}\right)$ oral exposure. The recent ban of food additive $\mathrm{TiO}_{2}$ (E171) use in France aggravated public controversy on safety of orally ingesting $\mathrm{TiO}_{2}$-NPs. This work aimed to determine biological effects of $\mathrm{TiO}_{2}-\mathrm{NPs}(38.3 \pm$ 9.3) oral consumption ( $100 \mathrm{mg} / \mathrm{kg}$ bw, 10 days) on TNBS-induced colitis mice and healthy mice, and the additional vitamin $\mathrm{E}$ administration was also conducted to explore the possible mechanism of $\mathrm{TiO}_{2}-\mathrm{NPs}$ on colitis development.

\section{Results}

Oral consumption of $\mathrm{TiO}_{2}$-NPs exacerbated oxidative stress status in colitis mice by decreasing the colonic glutathione (GSH) and total glutathione (T-GSH) levels, however, $\mathrm{TiO}_{2}-\mathrm{NPs}$ administration repaired the dysbacteriosis of colitis mice, and downregulated the Toll-like receptors (TLRs), nuclear factor kappaB (NF-KB) signal pathway and inflammatory factor (IL-1 $\beta$ and TNF-a) transcription levels in colon tissue, which finally decreased the TNF-a expression level and participated in the mitigation of colitis symptoms. Moreover, further vitamin $\mathrm{E}$ intervention after $\mathrm{TiO}_{2}$-NPs consumption could relieve the oxidative stress status (mainly by scavenging reactive oxygen species, ROS) and the inflammatory factor overtranscription in colonic epithelium of colitis mice, but the effect of $\mathrm{TiO}_{2}-\mathrm{NPs}$ on dysbacteriosis repair would not be further changed by Vitamin $\mathrm{E}$. At last, $\mathrm{TiO}_{2}$-NPs induced oxidative stress status and increased NF-KB signal transcription level in colonic epithelium, which increased daily disease activity index (DAl) score and caused mild mucosal inflammatory cell infiltrate in healthy mice.

\section{Conclusion}

Our present work showed that oral $\mathrm{TiO}_{2}-\mathrm{NPs}$ administration indeed induced oxidative stress and made an adverse effect on the development of colitis, but $\mathrm{TiO}_{2}$-NPs could also downregulate the NF-KB signal transduction level by repairing gut dysbacteriosis, which made a predominant role in alleviating colitis. On the other hand, it should also be noticed that $\mathrm{TiO}_{2}-\mathrm{NPs}$ oral ingestion caused potential colonic inflammation risks in healthy mice.

\section{Background}

The inflammatory bowel disease (IBD), which includes ulcerative colitis (UC) and Crohn's disease (CD), has been considered as an expanding global health challenge, with the western lifestyle largely contributing to their pathogenesis [1]. Currently, the aetiology of IBD still remains poorly understood, but it is generally accepted that the interaction of genetic and environmental factors play a decisive role in the pathogenesis of IBDs [2], and among the environmental factors are the increased 'Western diet', which 
include the ingestion of dietary $\mathrm{TiO}_{2}$ particles [3, 4]. In the progression of IBD, the oxidative stress and impaired mucosal immunity are considered as main pathomechanisms and have a long-standing implication [5]. Based on the integration of a series of clinical studies, patients with IBD and colitisassociated colorectal cancer generally got extremely heavy ROS load in the intestinal mucosa, the severe oxidative stress would further activate several key signal pathways, including NF-KB and mitogenactivated protein kinase (MAPK) signaling pathways to increase release of cytokines including TNF-a, IL$1 \beta$, IL- 6 and IL-8; moreover, some pro-inflammatory cytokines like TNF-a and IL- 6 would form feedback loops in NF-KB signaling to augment the inflammatory response and tissue damage [6].

$\mathrm{TiO}_{2}$ is one of the most promising engineered materials, which has been extensively used for whitening and brightening in foods, medicine and personal care products $[7,8,9]$. Food and pharma grade $\mathrm{TiO}_{2}$ are usually found both in the bulk form and as nanoparticle [3]. A test of food-grade $\mathrm{TiO}_{2}$ showed that approximately $10-36 \%$ of the particles used in food consist were $\mathrm{TiO}_{2}$-NPs (with diameter less than 100 $\mathrm{nm}$ ), and the proportion of NPs could be over $43 \%$ for some sweets such as the sugar-coated chewing gum $[9,10]$. Indeed, the daily intake of $\mathrm{TiO}_{2}$ was estimated to be $1.28 \mathrm{mg} / \mathrm{kg}$ bodyweight, especially the human dietary exposure dose of $\mathrm{TiO}_{2}-\mathrm{NPs}$ has reached 2.16 to $100 \mu \mathrm{g} / \mathrm{kg}$ bodyweight per day, and children or those with a sweet tooth were identified as having several times higher exposure values $[3,11$, 12]. Notably, these particles could be released and swallowed by humans upon chewing, thus consumers have actually come into direct contact with $\mathrm{TiO}_{2}$-NPs through food products.

$\mathrm{TiO}_{2}$ was traditionally considered as an inert and nontoxic substance for its insolubility, low absorption, and absence of toxic effects by the oral route, but recently the nanosized $\mathrm{TiO}_{2}$ has raised wide concerns about its potential health risk on gastrointestinal tract because of the small size, large surface area and high reactivity [13]. In in vivo studies, our previous works have clarified that $\mathrm{TiO}_{2}$-NPs ingestion could cause oxidative stress and induce liver, kidney as well as heart damage in young rats [14, 15], affect the amino acid absorption and metabolism of adult rats [16]. Nogueira et al. [17] found that the ingested $\mathrm{TiO}_{2}$-NPs were detected to form dark aggregates in M-cells of Peyer's patches and in underlying macrophages of mice intestinal tract, which could further influence the inflammatory cytokine production and induce inflammatory responses. Latterly Ruiz et al. [3] also reported that $\mathrm{TiO}_{2}-\mathrm{NPs}$ could active the NOD-, LRR- and pyrin domain-containing protein 3 (NLRP3) inflammasome in disuccinimidyl suberate (DSS)-induced colitis mice and worsen colonic inflammation. Except for the risk on inflammation inducement, $\mathrm{TiO}_{2}$-NPs was also reported to disturb the structure and function of gut microbiota as its unique antimicrobial compound, which was also suspected to influence the host health $[18,19]$. On the other side, extensive in vitro evidence have shown $\mathrm{TiO}_{2}-\mathrm{NPs}$ could effectively induce oxidative stress in intestinal cell culture systems including Caco-2, HT29, DLD-1, SW480 and NCM460 [20, 21, 22], and a limited number of in vivo studies also reported that $\mathrm{TiO}_{2}-\mathrm{NPs}$ oral exposure could promote the cytokine levels such as IL-1 $1 \beta$, IL-8, IL-12, TNF- $a$ and IFN- $\gamma$ in colonic mucosa of animals $[17,23]$. However, no in vivo study has directly focused on the relationship between the oxidative stress induced by $\mathrm{TiO}_{2}-\mathrm{NPs}$ oral 
exposure and the progression of IBD, nor has there been any attempt to explore other mechanisms such as signal pathway activation and gut microbiota impairment during this process.

In the present study, we analyzed the effect of $\mathrm{TiO}_{2}$-NPs on TNBS-induced acute colitis as well as the contribution of oxidative stress and NF-KB signal transcription during this process. For this purpose, we attempted to create 2,4,6-Trinitrobenzenesulfonic acid solution acute colitis model in the wild-type (WT) $\mathrm{BALB} / \mathrm{c}$ mice, and $\mathrm{TiO}_{2}$-NPs were orally administered to the colitis mice to study its effect on colitis symptoms. Meanwhile, we carefully detected the oxidative stress status, colonic micro ecology and NFKB signal transcription changes of mice to unravel biological mechanisms of NPs affecting colitis. Considering that antioxidant vitamin E could eliminate the ROS induced by $\mathrm{TiO}_{2}-\mathrm{NPs}$, some colitis model mice received additional vitamin $\mathrm{E}$ administration for further argument on the role of oxidative stress during the process $\mathrm{TiO}_{2}$-NPs changed the disease.

\section{Methods}

\section{1. $\mathrm{TiO}_{2}$ nanoparticles and physicochemical characterization}

In the present study, the food grade $\mathrm{TiO}_{2}$ nanoparticles were obtained from Shanghai Yunfu Nanotechnology Co. Ltd, China. A detailed report of $\mathrm{TiO}_{2}-\mathrm{NPs}$ physicochemical characterization was included in our early publications $[26,65]$. $\mathrm{TiO}_{2}$-NPs were anatase form with a purity of $99.95 \%$. The transmission electron microscopy (TEM, JEM-2100F, JEOL, Japan) showed that $\mathrm{TiO}_{2}$-NPs were nearly spherical shape, the primary size of nanoparticles ranged from $15.5 \mathrm{~nm}$ to $60.0 \mathrm{~nm}$, and the average primary diameter was measured as $38.3 \pm 9.3 \mathrm{~nm}$ (Figure 10A and 10B). The SSA of $\mathrm{TiO}_{2}-\mathrm{NPs}$ was measured as $61.87 \mathrm{~m}^{2} / \mathrm{g}$ according to the Brunauer-Emmett-Teller (BET) method (ASAP 2020, Micromeritics, Norcross, US). The hydrodynamic diameter, polydispersity index values (PDI) and Zeta potential of $\mathrm{TiO}_{2}$-NPs in ultrapure water $\left(\mathrm{H}_{2} \mathrm{O}\right)$, artificial gastric juice (AGJ) and artificial intestinal juice (AIJ) were tested by the ZetaSizer Nano ZS90 (Malvern Instruments Ltd, Malvern, UK). As shown in Figure 10C, $\mathrm{TiO}_{2}$-NPs got the largest distribution (range from $122.4 \mathrm{~nm}$ to $3579.6 \mathrm{~nm}$ ) after dispersed in $\mathrm{H}_{2} \mathrm{O}$, but the largest average hydrodynamic diameter was found when $\mathrm{TiO}_{2}$-NPs were dispersed in AGJ. Moreover, $\mathrm{TiO}_{2}$-NPs appeared the best dispersion stability which represented by largest absolute value of Zeta potential after their dispersion in AlJ.

\section{Animal treatment}

The WT BALB/c mice (8-week-old) were supplied and bred by the Department of Laboratory Animal Science, Peking University Health Science Center. The mice were maintained under specific pathogen-free (SPF), constant temperature $\left(20 \pm 2{ }^{\circ} \mathrm{C}\right)$ and humidity (50-70 \%), and a 12-hour light-dark cycle condition. All experiments were carried out in accordance with the Guiding Principles in the Use of Animals in Toxicology adopted by Society of Toxicology and the European Union Directive 2010/63/EU for animal 
experiments, and approved by the Institutional Animal Care and Use Committee in Peking University (approval number: LA2019216).

The TNBS solutions used for presensitization and colitis model establishment were set up based on the published studies [66]. 54 mice were randomly divided into 6 groups according to body weight (bw) after 5-day accommodation, 36 mice in 4 groups was treated with TNBS to induce acute colitis model, and the detailed report of the method used in the establishment of the mouse colitis model was included in the earlier publication by the author [65]. Briefly, after the 7-day administration of TNBS presensitization solution to the shaved back skin of mice, we conducted instillation of TNBS solutions in the colorectal tract of mice after they were anesthetized by $4 \%$ bacteria-free chloral hydrate solution (i.p., Sinopharm Chemical Reagent Co., Ltd. Beijing, China). All of mice were maintained in an ideal anesthetic state at 37 ${ }^{\circ} \mathrm{C}$ during colitis establishment, and held in a trendelenburg position to avoid solution backflow after the instillation. The timeline of the experimental protocol was shown in Figure 1E, healthy and colitis mice were separately intragastrically administrated with ultrapure water or $\mathrm{TiO}_{2}-\mathrm{NPs}$ dispersion $(100 \mathrm{mg} / \mathrm{kg}$ bw/day, newly prepared before gavage), once a day for 10 consecutive days. After the TNBS enema, two of the colitis model groups were additionally orally treated with vitamin $E$ dispersion ( $30 \mathrm{mg} / \mathrm{kg} \mathrm{bw} /$ day), once a day and lasted for 3 days. Feces samples used for subsequent microbiome analyses were collected late in Day 10. All of mice were harvested at Day 11, serum and organs including colon, intestine, liver, kidney, spleen and mesenteric lymph nodes were collected for further analyses.

\section{Evaluation of disease severity in mice}

\subsection{General condition assessment}

In the present study, the mice symptom, mortality and body weight change of mice during treatment were carefully observed and recorded daily. The residual and supplement feed were weighed daily to calculate the food intake, and the coefficient of feeding efficiency (CFE, \%) was calculated using the following equation:

$\mathrm{CFE}=($ total body weight gain $(\mathrm{g}) /$ total food intake $(\mathrm{g})) \times 100 \%$

After mice were sacrificed at Day 11, the colon, intestine, liver, kidney and spleen of animals were collected and washed in cold phosphate buffered saline (PBS, $\left.4^{\circ} \mathrm{C}\right)$, sucked dry with normal filters, and then weighted. The organ weight coefficient were calculated using the following equation:

The organ weight coefficient $=$ organ weight $($ wet, g) /body weight $(\mathrm{g}) \times 100 \%$

For pathological assessment, three mice were selected from every group based on the random principle and used, and all the histological examinations were performed following the standard laboratory procedure. Briefly, The excised colon and other tissues (including Jejunum, liver, kidney, spleen and mesenteric lymph nodes) were fixed in $4 \%$ buffered paraformaldehyde and embedded in paraffin blocks, then samples were sliced into $5 \mu \mathrm{m}$ thickness and placed onto glass slides. After slices were 
hematoxylin-eosin (HE) stained, the optical microscope (Olympus BX50, Moticam 2306, Japan) was used to observe slides and take photos. The identity and analysis of the pathology slides were blinded to the pathologist. Especially for the Jejunum tissue, the villi height and the crypt depth were measured based on our previous study [26] and the ratio of the villi height to the crypt depth was also calculated.

\subsection{Colitis activity assessment}

The colitis activity was evaluated by using the daily disease activity index (DAI) score, colon mucosal damage index (CMDI) score, and colon histopathological score according to the methods described in our earlier publication [65]. The DAI score was calculated basing on scores for weight reduction and faecal characterization (including consistency and hemoccult) [65]. For CMDI assessment, the colons of mice were opened by a midline incision and rinsed with cold PBS $\left(4^{\circ} \mathrm{C}\right)$. After the length of colon were measured, the structural damages of bowel wall were observed from luminal side under a magnifier. Meanwhile, the CMDI score was also assessed based on the colon traits and ulcer numbers according to the reported method [67]. And for histopathological score assessment, 3 intact colonic mucosa was randomly chosen from each slide. After the mucosal height was carefully measured, the histopathological damage score were assessed as absence of goblet cell and crypt as well as the degree of inflammatory cell infiltration according to the earlier publication by the author [65].

\subsection{Inflammation-related protein transcription and cytokines expression level measurement}

The mRNA transcription levels of TLRs (TLR-2 and TLR-4), NF-KB signal pathway (IKK-1, IKK-2 and p65) and inflammatory factors were measured in colon tissue ( 6 samples per group). About $50 \mathrm{mg}$ of colon tissue was homogenized and total RNA was extracted using Trizol (Hermo Fisher Scientific Inc, MA, USA). Concentrations of total RNA were determined with a spectrophotometer. The quality of isolated RNA was assessed by calculating the A260/ A280 ratio to ensure values between 1.8 and 2.0. SuperScript III Reverse transcriptase kit (Vazyme Biotech Co.,Ltd, Nanjing, China) was further used for the complementary DNA (cDNA) synthesis, the collected cDNA was quantified by quantitative real time polymerase chain reaction (PCR, Bio-Rad iCycler iQ5, Bio-Rad Co.,Ltd, the United states). The mRNA expression levels were normalized to Glyceraldehyde 3-phosphate dehydrogenase (GAPDH). Primers' sequences used in the present study were shown in the supplement information (Table S3).

The concentrations of TNF- $\alpha$ and IL-12 in serum and colon tissues ( 6 samples per group) were analyzed using ELISA Kit (Bioleaf Biotech Co.,Ltd, Shanghai, China) following the manufacturer's instructions. Briefly, colon tissues were homogenized in PBS buffer containing the protease inhibitors, then the supernatant was obtained after centrifugation at $3000 \mathrm{rpm}$ for $10 \mathrm{~min}$ at $4^{\circ} \mathrm{C}$. The tissue supernatants and serum samples were added into 96-well assay plates and incubated for $60 \mathrm{~min}$ at $37^{\circ} \mathrm{C}$. After further incubation with horseradish peroxidase(HRP)-Avidin at $37^{\circ} \mathrm{C}$, plates were detected on the microplate reader(FLUOstar Omega, BMG LABTACH, German) with the wavelength of $450 \mathrm{~nm}$. The calibration curve for each cytokine was generated with a five-parameter logistic fit. The detection limits for the cytokine assays were $1 \mathrm{pg} / \mathrm{mL}$. 


\section{Evaluation of oxidative stress status of mice}

\subsection{ROS production measurement}

In order to determine the ROS production in colon tissue, we obtained single-cell suspensions of colon epithelial cells through a 48nm nylon mesh (6 samples per group). ROS kits (Nanjing Jiancheng Bioengineering Institute, Nanjing, China) were used to measure ROS levels. According to the manufacturer's instructions, Dichloro-dihydro-fluorescein diacetate (DCFH-DA; $500 \mathrm{nM}$ ) was added to the suspensions and incubated for $60 \mathrm{~min}$ at $37^{\circ} \mathrm{C}$. Then cell suspensions were washed twice and resuspend with PBS. ROS-induced fluorescence was detected using a microplate reader (FLUOstar Omega, BMG LABTACH, German), with an excitation wavelength of $485 \mathrm{~nm}$ and an emission wavelength of $528 \mathrm{~nm}$.

\subsection{The glutathione peroxidase (GSH-px) vitality assessment}

The GSH-px activity in the colon tissue and serum was determined in the present study ( 6 samples per group). Briefly, $50 \mathrm{mg}$ frozen colon tissue was homogenized with 5 volumes (w/v) of extraction buffer and then the mixture was centrifuged at $4000 \mathrm{rpm}$ for $10 \mathrm{~min}$ to obtain supernatants. Similarly, serum samples were also diluted with extraction buffer at a ratio of 1:2 and then centrifuged to obtain supernatants. The GSH-px activity in supernatants were assayed with commercial GSH-px assay kit (Jiancheng Bioengineering Institute, Nanjing, China) following the manufacturer's instructions, and the absorbance was measured on the microplate reader at $412 \mathrm{~nm}$. The blank and background control were also set.

\subsection{Glutathione (GSH) content determination}

Total glutathione (T-GSH, including GSH and GSSG) levels in the colon tissue and serum were determined in the present study ( 6 samples per group). Briefly, $50 \mathrm{mg}$ frozen colon tissue was homogenized with 5 volumes $(\mathrm{w} / \mathrm{v})$ of homogenate medium provided by the manufacturer and then the mixture was centrifuged at 3500rpm for $10 \mathrm{~min}$ to obtain supernatants. Similarly, serum samples were also diluted with homogenate medium at a ratio of 1:4 and then centrifuged to obtain supernatants. Then T-GSH and GSSG content in the supernatant were determined by T-GSH/GSSG kits (Jiancheng Bioengineering Institute, Nanjing, China). The absorbance of the resulting yellow color was measured using a microplate reader at $420 \mathrm{~nm}$. To calculate the GSH/GSSG ratio, GSH (reduced form) was obtained by subtracting the $2 \times$ GSSG values from the total glutathione values.

\section{DNA extraction and microbial community analysis}

Feces samples for microbial community analysis were collected at Day 10 by using the Bacterial DNAFree Eppendorf Tubes (Eppendorf AG, Hamburg, Germany), and then stored at $-80^{\circ} \mathrm{C}$ immediately. DNA concentration and purity was monitored on $1 \%$ agarose gels, then DNA samples were diluted to $1 \mathrm{ng} / \mu \mathrm{L}$ using sterile water. 16S rRNA genes of distinct regions were amplified by using specific primer with the barcode (including 16S V4 515F-806R / 16S V3-V4 341F-805R / 16S V4-V5 515F-907R), and the primer sequences were shown as Table S4. All PCR reactions were carried out in a $30 \mu \mathrm{L}$ reaction based on the 
manufacturer's recommendations (Phusion ${ }^{\circledR}$ High-Fidelity PCR Master Mix, New England Biolabs). The same volume of $1 \times$ loading buffer (contained SYB green) was mixed to PCR products and operate electrophoresis on $2 \%$ agarose gel for detection, then mixture PCR products was purified with GeneJETTM Gel Extraction Kit (Thermo Scientific). Sequencing libraries were generated using lon Plus Fragment Library Kit 48 rxns (Thermo Scientific) following manufacturer's recommendations. The library quality was assessed on the Qubit@2.0 Fluorometer (Thermo Scientific). At last, the library was sequenced on an lon S5TM XL platform and 400 bp/600 bp single-end reads were generated.

Quality filtering on the raw reads were performed under specific filtering conditions to obtain the highquality clean reads according to the Cutadapt quality controlled process. Subsequently, reads were compared with the reference database using UCHIME algorithm to remove chimera sequences and obtain the effective sequence (Clean reads) for subsequent analysis. Uparse software (Uparse v7.0.1001) was used for sequences analysis, for sequences with similarity greater than $97 \%$ assigned to the same Operational Taxonomic Units (OTUs), then representative sequences with highest frequency in each OTU were annotated basing on Silva Database to obtain the taxonomic information. Community compositions of every sample were count at levels of kingdom, phylum, class. Order, family, genus and species. The Multiple sequence alignment were conducted by Using MUSCLE software (Version 3.8.31) to study phylogenetic relationship of different OTUs and the difference of the dominant species in different samples / groups. QIIME (Version1.7.0) and R software (Version 2.15.3) were used to calculate the Alpha diversity index (including Observed-species, Chao1, Shannon, Simpson, ACE, Good-coverage) and analyze complexity of species diversity. For Beta diversity index which used to evaluate differences of samples in species complexity, QIIME (Version1.7.0) was used to calculate the weighted unifrac distance of samples, and R software (Version 2.15.3) was used to conducted cluster analysis (including non-linear model NMDS method and PCA) based on the weighted unifrac distance. Moreover, we selected the first 10 genus with the highest abundance to draw a Taxtree, and ternary plot was used to compare the relative abundance of taxons between groups at different levels. Finally, we used the Tax4Fun package (taxon for function, based on KEGG database) in R software (Version 2.15.3) to predict the metabolic capacity based on $16 \mathrm{~S}$ results, and LefSe analysis were selected to detect significant differences among groups in the microbial function biomarkers (LDA Score $>2$ ).

\section{Statistical analysis}

Microbial community analysis were conducted based on methods described above. Data exhibited a normal distribution according to the Kolmogorov-Smirnov test were expressed as means \pm SD, and Oneway variance (ANOVA) with least significant difference (LSD) test was applied to evaluate the statistical significance of differences between the experimental groups and the control, otherwise the MannWhitney U test was applied. Analysis was carried out by using the Statistical Package for Social Sciences Version 22.0 (SPSS Inc., Chicago, IL, USA). A $p$ value less than 0.05 was considered to be statistically significant. 


\section{1. $\mathrm{TiO}_{2}$-NPs mitigated TNBS-induced colitis symptoms}

\subsection{The General condition of animals}

As shown in Figure 1A-1C, during the presensitization stage, appearance and social behavior of mice in all groups were normal, no difference in body weight changes or coefficient of feeding efficiency (CFE) was observed between groups, and animals were at slow growth status. After TNBS colorectal instillation at Day 7, we found that mice in TNBS group displayed the lowest body weight and CFE. However, the TNBS+VE group and $\mathrm{TNBS}+\mathrm{TiO}_{2}+\mathrm{VE}$ group displayed significant increase in body weight when compared with the TNBS group at Day 8, which indicated that vitamin E and its co-administration with $\mathrm{TiO}_{2}$-NPs could mitigate colitis symptom in weight loss.

Recent clinic researches have reported the appearance of extraintestinal manifestations (EIMs) in crohn's disease, and kidney, spleen, liver as well as biliary tract were the most frequently involved organs [24, 25]. As shown in Table 1, the organ weight coefficients of kidney and small intestine in TNBS group were significantly higher than the CT group, which indicated the potential organ injury during colitis inducement. Other experimental groups displayed significantly decreased kidney and small intestine organ weight coefficients when compared with TNBS group, which meant that the administration of $\mathrm{TiO}_{2}$-NPs and vitamin $\mathrm{E}$ as well as their co-administration could mitigate symptoms in organ injury. At last, no obvious difference was found in the coefficients of liver and spleen. As for pathological assessment, colitis mice in TNBS group and $\mathrm{TNBS}^{\mathrm{TiO}} \mathrm{Ti}_{2}$ group exhibited obvious renal pathological changes shown as glomerular hyperemia and hemorrhage, which would be further improved in TNBS+VE group and $\mathrm{TNBS}+\mathrm{TiO}_{2}+\mathrm{VE}$ group after colitis mice received vitamin $\mathrm{E}$ administration (Figure 2). Besides, no obvious pathological change could be observed in liver, spleen and mesenteric lymph nodes (Figure S1), which prompted the localized EIMs and no systemic inflammation was found. Especially for Jejunum, we noticed that $\mathrm{TiO}_{2}$ group and $\mathrm{TNBS}^{\mathrm{T}} \mathrm{TiO}_{2}$ group displayed significantly decreased villi height and villi height / crypt depth ratio when compared with CT group and TNBS group (Figure $\mathbf{S} 1$ and Table $\mathbf{S 1}$ ), indicating that $\mathrm{TiO}_{2}-\mathrm{NPs}$ could disturb villi structure of heathy and colitis mice, which was also consistent with findings in our previous publications $[16,26]$.

\subsection{Colitis activity of animals.}

The DAl has been developed to assess whether or not the colitis is progressing in clinic [27]. As shown in Figure 1D, the TNBS group displayed significantly elevated DAI score after the TNBS colorectal instillation when compared with the CT group, which represented active status of disease in colitis mice. Moreover, it could be noticed that $\mathrm{TNBS}+\mathrm{TiO}_{2}$ group, $\mathrm{TNBS}+\mathrm{VE}$ group and $\mathrm{TNBS}+\mathrm{TiO}_{2}+\mathrm{VE}$ group displayed significantly downregulated DAI scores when compared with the TNBS group from Day 8 to Day 10 , though still higher than the CT group, indicating the potentially supportive mitigation of $\mathrm{TiO}_{2}$ NPs and vitamin $\mathrm{E}$ as well as their co-administration on colitis activity. At last, we also found that $\mathrm{TiO}_{2}$ group displayed higher DAI score than the CT group during the late experimental administration, which 
suggested that oral $\mathrm{TiO}_{2}$-NPs administration was potential to arouse colonic inflammation risks in heathy mice.

For further assess the mucosal injury status of colon, the gross examination was conducted to reflect macroscopic damage status. As shown in Table 2, the TNBS group displayed significant shortening of length and notably elevated colon mucosal damage index (CMDI) score when compared with CT group, furthermore, we noticed lower $\mathrm{CMDI}$ scores and larger colon length of $\mathrm{TNBS}+\mathrm{TiO}_{2}$ group and $\mathrm{TNBS}+\mathrm{VE}$ group than the TNBS group, which meant $\mathrm{TiO}_{2}$-NPs and vitamin $\mathrm{E}$ helped to mitigate the macroscopic structure damages of acute colitis. Moreover, $\mathrm{TNBS}+\mathrm{TiO}_{2}+\mathrm{VE}$ group displayed larger colon length than the $\mathrm{TNBS}+\mathrm{TiO}_{2}$ group, indicating that effect of $\mathrm{TiO}_{2}-\mathrm{NPs}$ could be further enhanced after the coadministration with Vitamin E. At last, we also noticed the organ weight coefficients of colon in $\mathrm{TNBS}+\mathrm{TiO}_{2}$ group and $\mathrm{TNBS}+\mathrm{TiO}_{2}+\mathrm{VE}$ group were significantly higher than that in $\mathrm{TiO}_{2}$ group.

We further conducted pathological investigation to reflect the mucosal injury severity. As shown in Figure 3, H\&E stained sections of colonic tissue presented mild mucosal inflammatory cell infiltrates with intact epithelium in $\mathrm{TiO}_{2}$ group, which indicated epithelial inflammation risks after healthy mice received $\mathrm{TiO}_{2}$-NPs oral administration. Moreover, the TNBS group, $\mathrm{TNBS}+\mathrm{TiO}_{2}$ and TNBS+VE group exhibited obvious inflammatory cell infiltration as well as goblet cells and crypt structure loss, but these pathological changes seemed to be recovered in TNBS+TiO $2+\mathrm{VE}$ group after colitis mice received coadministration of $\mathrm{TiO}_{2}-\mathrm{NPs}$ and Vitamin E. Meanwhile, according to the result of pathological score assessment and mucosal height measurement (Table 2), the TNBS group and $\mathrm{TNBS}+\mathrm{TiO}_{2}$ group exhibited significantly higher pathological score and mucosal height than CT group and other experimental groups, which was similar to the result of gross examination, however, no significant difference could be observed between these two groups.

\section{2. $\mathrm{TiO}_{2}$-NPs downregulated NF-KB transcription and decreased cytokine levels in colitis mice}

Generally, nuclear factor KB (NF-kB) controlled transcription of inflammation genes in colonic epithelium. Classic activation of NF-KB could be initiated by a broad panel of different stimuli, including abnormal intestinal pathogen through TLRs or colonic tissue damage from oxidative stress [6]. On activation, NF-KB was rapidly released from cytoplasmic inhibitor (inhibitor of NF-KB, IKB) with the function of IKKs, transmigrated into the nucleus, and bound to DNA response elements in gene promoter regions $[28,29]$. In the present study, we detected mRNA transcription levels of the NF-KB signal pathway in the colonic tissue of animals. As shown in Figure 4 and Figure $\mathbf{S 2}$, oral $\mathrm{TiO}_{2}-\mathrm{NPs}$ exposure significantly increased mRNA expression of P65 (subunit of NF-KB) in healthy mice. Meanwhile, the TNBS group showed significantly increased transcription levels of TLR-2, TLR-4, IKK2 and NF-KB P65 when compared with the CT group, which suspected an active NF-KB signal transcription in colon tissue of colitis mice. However, the transcription level of TLR-2, IKK2 and NF-KB P65 significantly decreased in the $\mathrm{TNBS}+\mathrm{TiO}_{2}$ group after colitis mice received additional $\mathrm{TiO}_{2}-\mathrm{NPs}$ administration, and the transcription level of NF-KB P65 
also downregulated in the TNBS+VE group, which meant that both $\mathrm{TiO}_{2}-\mathrm{NPs}$ and vitamin $\mathrm{E}$ administration could downregulated the NF-KB signal transcription level in colon tissue of colitis mice.

Among the downstream signaling events of NF-KB signal pathway, the inflammatory molecules and biomarkers transcription were believed to participate in immune-mediated injury in the gut and promote the progression of IBD [6]. In the present work, we found that healthy mice in $\mathrm{TiO}_{2}$ group displayed higher TNF-a mRNA transcription level than CT group. Meanwhile, colitis mice in the TNBS group showed significantly higher IL-1 $\beta$, IL-10 and TNF- $a$ transcription level in colon tissue when compared with healthy ones in the CT group, and the transcription level of HSP-90 also significantly decreased at the same time. Moreover, we noticed that the elevated IL-1 $\beta$ and TNF-a transcription level in TNBS group could be downregulated after colitis mice received $\mathrm{TiO}_{2}$-NPs administration, and the transcription level of antiinflammatory cytokine IL-10 could also be further upregulated, indicating that $\mathrm{TiO}_{2}$-NPs administration could participate in reducing inflammation level of TNBS-induced acute colitis.

We also detected the expression level of typical inflammatory factors including TNF-a and IL-12 by Enzyme-linked immunosorbent assay (ELISA). As shown in Table 3, colitis mice in the TNBS group showed significantly higher TNF-a secretion level in colon tissue when compared with the CT group, and the $\mathrm{TNBS}+\mathrm{TiO}_{2}$ group, $\mathrm{TNBS}+\mathrm{VE}$ as well as $\mathrm{TNBS}+\mathrm{TiO}_{2}+\mathrm{VE}$ group further displayed lower TNF-a level than the TNBS group, which was consistent with changes of TNF-a mRNA transcription level. Besides, the serum TNF-a and IL-12 contents were also detected to measure systemic inflammation levels of animals, no significant change was found in serum contents of cytokines in the TNBS group when compared with the CT group, which meant the localized inflammation after acute colitis inducement. However, we noticed that $\mathrm{TiO}_{2}$ group showed higher serum IL-12 level when compared with the CT group, which prompted $\mathrm{TiO}_{2}$-NPs administration could induce potential inflammation risk in healthy mice.

\section{$3 \mathrm{TiO}_{2}-\mathrm{NPs}$ triggered oxidative stress in colitis mice.}

The body has antioxidant defenses mainly consisted of intracellular enzymatic antioxidants and nonenzymatic antioxidant glutathione to counteract the effects caused by ROS, and the uncontrolled oxidative stress was destructive to the $\mathrm{Gl}$ tract and has been proved as an important pathogenic mechanism of IBD $[3,5]$. As shown in Table 4, we found that the glutathione peroxidase (GSH-px) vitality, T-GSH, oxidized glutathione (GSSG) as well as GSH content, but not the GSH / GSSG ratio, were significantly decreased in colon tissue of $\mathrm{TiO}_{2}$ group after healthy mice received $\mathrm{TiO}_{2}$-NPs administration. Meanwhile, the significant ROS accumulation and decreased GSH-px vitality, GSH, T-GSH content and GSH/GSSG ratio could be observed in the TNBS group when compared with the CT group, indicating severe oxidative stress in colon tissue of colitis mice. Furthermore, the GSH and T-GSH content in $\mathrm{TNBS}+\mathrm{TiO}_{2}$ group was lower than those in TNBS group, which meant that $\mathrm{TiO}_{2}-\mathrm{NPs}$ administration were potential to increase the antioxidant consumption and aggravate oxidative stress status in colon tissue of colitis mice. At last, the TNBS+VE group and $T N B S+\mathrm{TiO}_{2}+\mathrm{VE}$ group displayed significant decreased ROS accumulation in colon tissue when compared with colitis mice in TNBS group, but the GSH content 
and GSSG / GSH ratio were not obviously changed, which was in consistent with vitamin E's capability to scavenge oxygen free radical and prompted its effect on balancing oxidative stress in TNBS-induced acute colitis [30].

On the other hand, we also detected the GSH-px vitality and glutathione content in serum to reflect the systemic oxidative stress status of animals. As shown in Table 5, except for the significantly decreased serum GSH-px vitality in the $\mathrm{TNBS}+\mathrm{TiO}_{2}$ group when compared with $\mathrm{CT}$ group and other experimental groups, no significant change could be found in remaining indicators, which meant that acute colitis inducement would not lead to systemic oxidative stress in animals, and $\mathrm{TiO}_{2}$ administration was suspected to induce systemic oxidative stress risks in colitis mice.

\section{4. $\mathrm{TiO}_{2}-\mathrm{NPs}$ repaired gut dysbacteriosis of colitis mice}

\subsection{Richness and evenness of gut microbiota in mice}

Previous studies have pointed out that compositional and metabolic changes in the gut microbiota were major driver of IBD [31], thus microbial community profiles were created by clustering 16S rRNA sequences into operational taxonomic units. The rarefaction and rank abundance curves exhibited the plateau and indicated the vast majority of bacterial species in the samples had been covered (Figure S3). As shown in Table 6, we observed significant increase of the ACE and Chao1 richness estimator in the TNBS group when compared with the CT group, which indicated the imbalance of gut microbiome richness in colitis mice. Moreover, further downregulation of Chao1 index could be found in the $\mathrm{TNBS}+\mathrm{TiO}_{2}$ group than TNBS group after colitis mice received administration of $\mathrm{TiO}_{2}-\mathrm{NPs}$, indicating that imbalance of gut microbiome richness in colitis mice would be partly repaired by $\mathrm{TiO}_{2}-\mathrm{NPs}$. Similar changes could also be observed on other richness estimators like Shannon, Simpson, observed species and PD whole tree index, though without significance.

Venn's diagram in Figure $\mathbf{S} 4$ showed that all of the groups shared the compositional overlap of 377 core microbiota, these overlapping phylotypes contributed to majority of the CT group and $\mathrm{TiO}_{2}$ group, which shared proportion of $99.4 \%$ and $98.4 \%$ respectively. Meanwhile, more unique phylotypes were observed in colitis mice, among which the $\mathrm{TNBS}+\mathrm{TiO}_{2}$ group displayed the highest proportion of $10.8 \%$. As shown in Figure $5 \mathrm{~A}$, the histogram generated by clustering analysis at phylum level divided the mouse feces samples into four major groups, the CT group, the $\mathrm{TiO}_{2}$ group and TNBS group, the TNBS+VE and $\mathrm{TNBS}+\mathrm{TiO}_{2}+\mathrm{VE}$ group, as well as the $\mathrm{TNBS}+\mathrm{TiO}_{2}$ group. Noticeably, Firmicutes predominated in feces samples of the $\mathrm{TiO}_{2}$ group and TNBS group, while Bacteroidetes mainly distribute in faecal of other groups. And it could also be observed that the relative abundance of Proteobacteria in the $\mathrm{TNBS}^{\mathrm{TiO}} \mathrm{Ti}_{2}$ group was higher when compared with other experimental groups. The Non-metric multidimensional scaling (NMDS) analysis showed that the samples of different groups were distinguished clearly (Figure 5B, stress $=0.191<0.200$ ), suggesting a diverse gut microbiota composition among groups. Meanwhile, the results of 3D-principal component analysis (PCA) on evenness (Figure 5C) also showed significantly different microbial composition among groups (Amova, $p<0.001$ ). Compared with CT group, 
the obvious dissimilarities of gut microbiota composition were found in TNBS group, TNBS+VE and $\mathrm{TNBS}+\mathrm{TiO}_{2}+\mathrm{VE}$ group. And after colitis mice received the single administration of $\mathrm{TiO}_{2}-\mathrm{NPs}$ or the coadministration of $\mathrm{TiO}_{2}$-NPs and vitamin $\mathrm{E}$, obvious separations of gut microbiota composition could be further observed in the $\mathrm{TNBS}+\mathrm{TiO}_{2}$ group and $\mathrm{TNBS}+\mathrm{TiO}_{2}+\mathrm{VE}$ group when compared with the TNBS group.

\subsection{Microbial phylotype composition in mice}

The classification of specific taxonomy groups of species was conducted and shown as Figure 6, Firmicute (27.50\%), Bacteroidetes (16.09\%), Proteobacteria (7.13\%) and Deferribacteres $(0.91 \%)$ were four major phylum in feces samples of mice. Meanwhile, Proteobacteria phylum was primarily composed of Gammaproteobacteria-Stenotrophomonas strain (7.13\%), Deferribacteres phylum mainly consisted the Deferribacteres-Mucispirillum strain $(0.91 \%)$, and the $\mathrm{TNBS}^{\mathrm{T}} \mathrm{TiO}_{2}$ group shared the highest relative abundance proportion of these two strains. Moreover, Firmicutes phylum was primarily composed of Lactobacillaceae (15.69\%), Enterococcaceae (1.32\%), Ruminococcaceae (8.22\%) and Lachnospiraceae $(2.27 \%)$ at the family level, and it could be noticed that the $\mathrm{TiO}_{2}$ group, TNBS group as well as the $\mathrm{TNBS}+\mathrm{TiO}_{2}+\mathrm{VE}$ group shared high relative abundance proportion of the first three taxonomy, respectively (Table S2). Then for other taxonomy at different levels, the classification of bacteria tended to be dispersed in groups and it would be hard to determine the dominant.

Furthermore, Ternary plot analysis was conducted to determine the predominant taxonomy among groups at the classification from phylum to genus. As shown in Figure 7, the RuminococcaceaeClostridium_papyrosolvens strain, Enterococcus_faecalis, Bacteroides_acidifaciens and Lachnospiraceae_bacterium_A4 from family to genus level dominantly distributed in the TNBS group when compared with the CT group. The Proteobacteria-Stenotrophomonas strain, Mucispirillum and Mucispirillum_schaedleri from phylum to species level dominantly distributed in the $\mathrm{TNBS}+\mathrm{TiO}_{2}$ group when compared with the CT group and TNBS group. These results indicating the dominance of pathogenic flora in colitis mice and intervention effect of $\mathrm{TiO}_{2}$-NPs on phylotype composition of colitis mice. Moreover, we noticed that the co-administration with vitamin E would not markedly change the effect of $\mathrm{TiO}_{2}$-NPs on phylotype composition of colitis mice, except for the dominance of Ruminococcaceae-Clostridium_papyrosolvens stain in the $\mathrm{TNBS}+\mathrm{TiO}_{2}+\mathrm{VE}$ group when compared with the $\mathrm{TNBS}+\mathrm{TiO}_{2}$ group (Figure S5).

\subsection{Gut-associated functional category of gut microbiota in mice}

It was known that changes in gut microbiota structure could affect the gut-associated function by providing modifications to gut microbiota that would affect molecule, enzyme, metabolism, biosynthesis and signal pathway. Thus the Tax4Fun analysis as well as LDA effect size (LEfSe) analysis were used to predict the functional profiles of gut microbiota based on the Kyoto Encyclopedia of Genes and Genomes (KEGG) database. When compared with the CT group, we observed that functional category "ovarian_Steroidogenesis" and "Secretion_systerm" were significantly enriched in the $\mathrm{TiO}_{2}$ group, while 
"Enzyme_families", "amino_sugar_and_nucleotide_sugar_metabolism" and "lipid metabolism" were also diminished at the same time (Figure 8A). Moreover, enhanced amino acid biosynthesis function (including "Arginine_biosynthesis", "Phenylalanine_tyrosine_and_tryptophan_biosynthesis” and "Valine_leucine_and_isoleucine_biosynthesis"), "Butanoate_metabolism", "Protein_folding_and_associated_processing”, "Methane_metabolism”, "Nitrotoluene_degradation” and "AMPK_signaling_pathway" could be observed in the TNBS group when compared with the CT group, but functional category "Galactose_metabolism" were diminished (Figure $\mathbf{8 B}$ and $\mathbf{8 C}$ ). Meanwhile, oral $\mathrm{TiO}_{2}{ }^{-}$ NPs administration significantly enriched the category "Phenylalanine_metabolism" of colitis mice in $\mathrm{TNBS}+\mathrm{TiO}_{2}$ group (Figure 8B), while vitamin E administration enriched the category "Pathogenic_Escherichia_coli_infection" in TNBS+VE group (Figure 8C). At last, no functional category was significantly changed after the co-administration of $\mathrm{TiO}_{2}-\mathrm{NPs}$ and vitamin $\mathrm{E}$.

\section{Discussion}

\section{1. $\mathrm{TiO}_{2}$-NPs mitigated TNBS-induced acute colitis by decreasing NF-KB signal transcription}

In the present study, we focused on the effect of oral $\mathrm{TiO}_{2}-\mathrm{NPs}$ administration on development of TNBSinduced colitis. As shown in the Additional File j, the TNBS-induced acute colitis mice displayed dysbacteriosis and oxidative stress status in the colonic epithelium, as a result, the upstream activators (including TLRs and IKKs) of NF-KB-p65 would pervasively transcript and active the NF-KB signaling pathway, which finally increasing the inflammation levels in colonic epithelium and inducing disease activity in animals. Meanwhile, we noticed that $\mathrm{TiO}_{2}-\mathrm{NPs}$ administration seemed to be able to partly reverse the whole process in colitis mice (Figure 9 and Additional File $\mathbf{k}$ ). $\mathrm{TiO}_{2}$-NPs administration still triggered oxidative stress status in the colonic epithelium of colitis mice, but also decreased the relative abundance of some pathogenic strains to repair the dysbacteriosis, further downregulated the TLRs and $\mathrm{NF}-\mathrm{KB}$ signal transcription and inflammatory factor levels in colonic epithelium, and finally participated in the mitigation of TNBS-induced acute colitis.

The precise etiology of IBD remained unclear, present clinic studies have confirmed that the uncontrolled oxidative stress status would be a mechanism underlying the pathophysiology of IBD [30]. The oxidative stress status in colonic epithelium could activate nuclear factor-kB signal pathway transcription and promote release of pro-inflammatory cytokines [32, 33]. It was found in previous researches that $\mathrm{TiO}_{2}-\mathrm{NPs}$ could induce decreased antioxidant enzyme activity and increased ROS accumulation in the colon of mice, which further leading to adverse consequences such as inflammatory cell recruitment, proinflammatory factor expression and abnormal proliferation of epithelium [34, 35], and it was also suspected that $\mathrm{TiO}_{2}$-NPs might exacerbate inflammation risks of colitis by inducing excessive oxidative stress [32]. In the present study, we did find that $\mathrm{TiO}_{2}-\mathrm{NPs}$ administration significantly downregulated TGSH and GSH content and partly upregulated ROS accumulation $(p=0.13)$ in colonic epithelium of colitis mice. As the most abundant low molecular weight thiol compound synthesized in cells, GSH could play a critical role in protecting cells from oxidative damage and xenobiotic electrophiles toxicity, as well as help 
to maintaining the redox homeostasis [36], thus we agreed that $\mathrm{TiO}_{2}-\mathrm{NPs}$ induce antioxidant system disorders and aggravate oxidative stress in colonic epithelium of colitis mice. However, colitis mice displayed downregulated inflammatory factor levels and disease activity index after oral $\mathrm{TiO}_{2}-\mathrm{NPs}$ administration, which indicated the mitigation effect of $\mathrm{TiO}_{2}-\mathrm{NPs}$ on colitis and this should be independent of oxidative stress aggravation effect of $\mathrm{TiO}_{2}$-NPs. For better demonstration on this view, some colitis mice in the present study also received co-administration of $\mathrm{TiO}_{2}$-NPs and vitamin $\mathrm{E}$. As an effective free radical scavenger, vitamin $E$ has been well established to exert excellent antioxidant effect through hydrogen atom transfer reaction to yield non-radical product [37, 38]. According to present results, colitis mice received co-administration of $\mathrm{TiO}_{2}$-NPs and vitamin E displayed significantly lower ROS accumulation in colonic epithelium when compared with those only received $\mathrm{TiO}_{2}-\mathrm{NPs}$, thus it could be conducted that vitamin E effectively scavenged the ROS and antagonized with the oxidative stress status induced by $\mathrm{TiO}_{2}$-NPs. We also noticed that vitamin $\mathrm{E}$ helped to enhance the mitigation effect of $\mathrm{TiO}_{2}$-NPs on colitis, suggested that the $\mathrm{TiO}_{2}$-NPs induced oxidative stress made an adverse effect on the development of colitis. Hence, we believed that $\mathrm{TiO}_{2} \mathrm{NPs}$ alleviated colitis through other pathways which made promoting effect, and the significance was far greater than the adverse effect of oxidative stress. Further effort should be taken to fully explain the mechanism.

On the other side, the inappropriate response of dysfunctional mucosal immune system to the resident microbiota and other noxious antigens was also central to the development of IBD [28]. Previous studies also proved that $\mathrm{TiO}_{2}$-NPs could possess excellent antimicrobial activity for its nanostructure, large specific surface area (SSA) and high surface activity, which was suspected to change the microbial composition in in vivo and in vitro $[34,35,39]$. In the present work, we found that $\mathrm{TiO}_{2}-\mathrm{NPs}$ significantly corrected the imbalanced richness as well as evenness of gut microbiota, and changed predominant taxonomy in colitis mice, including decreased relative abundances of Enterococcus_faecalis and Bacteroides_acidifaciens, and increased relative abundance of Mucispirillum_schaedleri . On the basis of microbiology research, increased abundance of Enterococcus_faecalis and Bacteroides_acidifaciens are both prominent features in patients with CD and UC [40,41], among which Enterococcus_faecalis could release metalloprotease to compromise epithelial barrier, further induce the overexpress of proinflammation cytokines (including IL-6-IL-17a and IL-23a) and clinically active disease in patients [42, 43], besides, Bacteroides_acidifaciens was found to produce significant starting point to inflammatory cascades and eventually lead to development of IBD [44]. According to the correlation analysis (Figure S6A and S6C), we found that relative abundance of Enterococcus_faecalis and Bacteroides_acidifaciens were positively correlated with NF-KB signal transcription level in colonic epithelium (including IKKs, NFKB-p65 and IL-1 $\beta$ mRNA level) and colitis symptom indicators (including elevated DAI and CMDI score as well as decreased body weight). Except for changes of pathogenic strains, model research also pointed out that Mucispirillum_schaedleri could help to improve the functional mucus layer in the gut and conferred protection against colitis in mice [45], our correlation analysis also showed that relative abundance of Mucispirillum_schaedleri was negatively correlated with TNF-a expression level in colon tissue. Collectively, considering the shift of dominantance from pathogenic strains to probiotic in gut 
microecology of colitis mice after $\mathrm{TiO}_{2}$-NPs oral administration, we believed it could be an important mechanism that $\mathrm{TiO}_{2}$-NPs participated in the mitigation of TNBS-induced colitis.

Furthermore, as the most common pattern-recognition receptors, TLRs could sense and recognize pathogen-associated molecular patterns (PAMPs) [46]. Upon their activation under stress of gut dysbacteriosis, TLRs could mediate the phosphorylation of IKB to activate NF-KB signal transduction cascade and induce the overexpression of inflammatory cytokines [28]. Hausmann et al. [47] detected biopsy samples from patients with active IBD and found that the colonic epithelial layer showed significant positive staining for TLR2 and TLR4, meanwhile the mRNA transcription of pro-inflammatory cytokines such as IL-1 $\beta$ was also significantly upregulated. By now few previous work had explored the effect of $\mathrm{TiO}_{2}$-NPs on gut TLRs, but present work suggested that the decreased relative abundance of pathogenic strains and gut dysbacteriosis stress after $\mathrm{TiO}_{2}-\mathrm{NPs}$ administration could interact with the decreased TLRs transcription level in colitis mice, which would further induce the lower transcription of IKK2 and NF-KB p65, finally contribute to the downregulation of IL-1 $\beta$ and TNF- $\alpha$ as well as the inflammation suppression. Except for the changes of pro-inflammatory signal transcription, we also found that $\mathrm{TiO}_{2}$-NPs administration would increase IL-10 mRNA transcription in colitis mice. Previous work reported that chronic food-grade $\mathrm{TiO}_{2}$ administration could significantly increased IL-10 expression in rat colon [23]. As an important anti-inflammatory cytokine, IL-10 was proved to block IKK activation and directly inhibit the nuclear localisation of the NF-KB p65/p50 heterodimer, which participated in resolution of many major inflammatory response and contributed to wound healing $[48,49,50]$. Thus we believed that the biological effect of $\mathrm{TiO}_{2}$-NPs on increasing IL-10 mRNA transcription could also participate in the mitigation of TNBS-induced colitis, and the mechanism could also be related with the effect of $\mathrm{TiO}_{2}$-NPs on increasing relative abundance of Mucispirillum_schaedleri (Figure S6C).

Taken together, $\mathrm{TiO}_{2}$-NPs could aggravate oxidative status in colonic epithelium of colitis mice and repair the gut dysbacteriosis at the same time, but it was the latter rather than former made the predominant role and downregulated the NF-KB signal transcription and inflammation level, which finally contributed to the mitigation TNBS-induced acute colitis. Due to its unique properties, there has been an increase in biomedical applications of $\mathrm{TiO}_{2}$-NPs such as drug delivery, bioimaging, photoablation therapy and biosensors [51]. Recently, the application of $\mathrm{TiO}_{2}$-NPs conjugated with specific monoclonal antibody has been proved to photokill human metastatic colon adenocarcinoma (LoVo) cancer cells effectively [52]. However, the safety of $\mathrm{TiO}_{2}$-NPs in the oral drug delivery system has long been concerned [53]. Our research provided a new understanding about oral intake of $\mathrm{TiO}_{2}-\mathrm{NPs}$, this material actually exhibited mitigation effects for individuals with colitis, and it could be an important inspiration for the safe biomedical application of $\mathrm{TiO}_{2}$-NPs, though further effort on clinic research was still needed.

\section{2. $\mathrm{TiO}_{2}{ }_{2} \mathrm{NPs}$ induced oxidative stress and colonic inflammation risks in healthy mice.}

Except for the effect of $\mathrm{TiO}_{2}$-NPs on acute colitis, the present study also investigated the inflammation risk of healthy mice after ingesting $\mathrm{TiO}_{2}-\mathrm{NPs}$. As shown in Figure $\mathrm{S7}, \mathrm{TiO}_{2}-\mathrm{NPs}$ induced oxidative stress 
status and increased NF-KB signal transcription level in colonic epithelium, meanwhile, $\mathrm{TiO}_{2}-\mathrm{NPs}$ influenced the prediction of gut microbiota functions, though not be able to change predominant taxonomy in healthy mice.

The disorder of glutathione antioxidant system in colon tissue showed as downregulated GSH and T-GSH content as well as the decreased GSH-px activity. As the most effective antioxidant against hydroperoxides in cells, GSH-px provides the most vital defense against the peroxidative damage of biological membranes in mammalian cells [54]. Previous clinic researches reported a significantly decreased serum GSH-px activity in IBD active patients when compared with healthy controls [55], and in vivo studies also found that oral $\mathrm{TiO}_{2}-\mathrm{NPs}$ exposure could induce decreased GSH-px activity in liver, kidney, brain and serum of rats and mice, which further lead to organ inflammation as well as functional disorders [56, 57]. Li et al. [58] and Hugo et al. [59] pointed out that the antioxidant activity of GSH-px played an important role in inhibiting IKKs activity and NF-KB signaling pathway activation. In the present work, the NF-KB signaling transcription level (including NF-KB-P65 and TNF- $a$ ) in colonic epithelium of healthy mice was significantly upregulated after oral $\mathrm{TiO}_{2}$-NPs ingestion, but the transcription level of IKKs were not obviously changed, thus only limited evidence support that the oxidative stress status induced by $\mathrm{TiO}_{2}$-NPs administration could induce inflammation by activing NF-KB signal transcription.

Moreover, we also found that $\mathrm{TiO}_{2}$-NPs administration changed prediction of gut microbiota functions in healthy mice, such as the reduced function in amino_sugar_and_nucleotide_sugar metabolism as well as lipid metabolism. Metabolic studies also pointed out these functional category changes were potential to disturb lysine acetylation and SCFA synthesis, which could influence the colonic barrier function in host and result in inflammation risks $[60,61]$. On the other side, the ternary plot analysis suggested that no significant dominant distribution of taxonomy was reserved in the $\mathrm{TiO}_{2}$ group when compared with CT group and TNBS group, which meant the effect of $\mathrm{TiO}_{2}$-NPs on microbial phylotype composition could be scant and not be able to induce obvious gut dysbacteriosis, especially when compared with the TNBScolitis inducement. Meanwhile, considering that the transcription levels of TLRs were also not significantly changed, we didn't think $\mathrm{TiO}_{2}$-NPs administration could upregulate the NF-kB signal transcription by improving TLRs transcription and recognizing PAMPs caused by gut dysbacteriosis stress.

Except for the upregulated mRNA transcription of pro-inflammation factors in colonic epithelium, we also noticed that the serum IL- $12 \beta$ level increased after healthy mice orally exposed to $\mathrm{TiO}_{2}-\mathrm{NPs}$. Previous studies found that $\mathrm{TiO}_{2}$-NPs exposure by intratracheal instillation could significantly increase IL-12 $\beta$ serum level in a dose-dependent manner in mice, while oral exposure to $\mathrm{TiO}_{2}$-NPs also induced overexpression of IL-12 $\beta$ in liver and intestine of mice $[17,62]$. As an important pro-inflammatory cytokine, IL-12 $\beta$ participated in inducing naive $C D 4+T$ cells to differentiate into Th1 cells, which could be implicated in the etiology of a number of human autoimmune diseases [63]. Clinic researches also reported that serum IL-12 $\beta$ levels were positively correlated with clinical and endoscopic disease activity in IBD patients, which suggesting it as a biomarker for assessing disease activity [64]. In present study, 
histological examination displayed mild inflammatory cell infiltrates in colonic mucosa of healthy mice after oral $\mathrm{TiO}_{2}$-NPs administration, which could be strong mutual corroboration with serum IL-12 $\beta$ changes and suggested the odds of inflammation risks.

In short, the present study prompted that $\mathrm{TiO}_{2}$-NPs ingestion induced inflammation risks in the colonic epithelium of healthy mice, the oxidative stress status or functional category changes caused by $\mathrm{TiO}_{2}-$ NPs might be interrelated with the whole process but should not be the driving factors, and further efforts were also recommended to investigate the possible mechanism.

\section{Conclusion}

In summary, findings in our present study showed that orally administered $\mathrm{TiO}_{2}$ nanoparticles could mitigated the TNBS-induced acute colitis through the repairs to gut dysbacteriosis and downregulation of $\mathrm{NF}-\mathrm{KB}$ signal transcription. $\mathrm{TiO}_{2}$-NPs indeed exacerbated oxidative stress status in colonic epithelium of colitis mice, but the co-administration with vitamin $\mathrm{E}$ also demonstrated that the mitigation of $\mathrm{TiO}_{2}-\mathrm{NPs}$ on colitis was independent from their effect on oxidative stress inducement. It could be suspected that the promoting effect of flora imbalance repair was far greater than the adverse effect of oxidative stress induced by $\mathrm{TiO}_{2}-\mathrm{NPs}$ on colitis mice. Considering the prospective bio-effect of $\mathrm{TiO}_{2}-\mathrm{NPs}$, we strongly recommended more chronic colitis experiments to be carried out in the future to provide an insight into the potential role of $\mathrm{TiO}_{2}-\mathrm{NPs}$ in alleviating the disease.

Meanwhile, we also noticed that $\mathrm{TiO}_{2}-\mathrm{NPs}$ induced upregulated NF-kB signal transcription and potential inflammation risks in healthy mice. Since the use of $\mathrm{TiO}_{2}$-NPs as food additive and medical adjuvant is on the rise, more cautious use of these particles was suggested before we got biologically relevant exposure information to facilitate interpretation of their safety.

\section{Abbreviations}

TNBS: 2,4,6-Trinitrobenzenesulfonic

$\mathrm{TiO}_{2}$ : Titanium dioxide

$\mathrm{TiO}_{2}$-NPs: Titanium dioxide nanoparticles

ROS: reactive oxygen species

GSH: glutathione

T-GSH: total glutathione

TLRs: Toll-like receptors 
NF-kB: nuclear factor kappa-B

DAl: Disease activity index

IBD: inflammatory bowel disease

UC: ulcerative colitis

CD: Crohn's disease

MAPK: mitogen-activated protein kinase

NLRP3: NOD-, LRR- and pyrin domain-containing protein 3

DSS: disuccinimidyl suberate

WT: wild-type

CFE: coefficient of feeding efficiency

EIMs: extraintestinal manifestations

CMDI: colon mucosal damage index

IKB: inhibitor of NF-Kb

ELISA: Enzyme-linked immunosorbent assay

GSH-px: glutathione peroxidase

GSSG: oxidized glutathione

NMDS: Non-metric multidimensional scaling

PCA: principal component analysis

LefSe: LDA effect size

KEGG: Kyoto Encyclopedia of Genes and Genomes

SSA: specific surface area

PAMPs: pathogen-associated molecular patterns

TEM: transmission electron microscopy

BET: Brunauer-Emmett-Teller 
AGJ: artificial gastric juice

PDI: polydispersity index values

AlJ: artificial intestinal juice

SPF: specific pathogen-free

PBS: phosphate buffered saline

HE: hematoxylin-eosin

cDNA: complementary DNA

PCR: polymerase chain reaction

GAPDH: Glyceraldehyde 3-phosphate dehydrogenase

HRP: horseradish peroxidase

DCFH-DA: Dichloro-dihydro-fluorescein diacetate

OTUs: Operational Taxonomic Units

ANOVA: One-way variance

LSD: least significant difference

\section{Declarations}

\section{Ethics approval and consent to participate}

The animal experiments were carried out in accordance with the Guiding Principles in the Use of Animals in Toxicology adopted by the Society of Toxicology and the European Union Directive 2010/63/EU for animal experiments and received approval from the Peking University Institutional Review Board (LA2019216).

\section{Consent for publication}

Not applicable.

\section{Availability of data and materials}

The relevant datasets supporting the conclusions of this article are included within the article, and all datasets used and analyzed during the current study are available from the corresponding author on reasonable request. 


\section{Competing interests}

The authors declare that they have no competing interests.

\section{Funding}

This work was supported by the National Natural Science Foundation of China (31971313), and the Beijing Natural Science Foundation (7172116).

\section{Authors' contributions}

YW conceived and guided the present study. YJG and SMD designed the present study and conducted the animal experiments. YJG interpreted all of the data and wrote the manuscript. $L Z L, X W X, X X O$ and $L X$ participated in the animal experiments and graphically designed the figures. All authors read and approved the final manuscript.

\section{Acknowledgments}

The authors gratefully acknowledge the support from Yuze Qi, Huihui Quan, Changmao Long, Jingshu Zhang and Feng Cao in the experiment as well as the support from Zhaonian Wang and Tingyu Li in the data analysis stage.

\section{Corresponding author}

Correspondence to Yun Wang.

\section{Authors' information}

Yanjun Gao, Shumin Duan, Lizhi Lyu, Weixing Xu, Xiaxian Ou, Lin Xu, Yun Wang*

Department of Occupational and Environmental Health Sciences, School of Public Health, Peking University, Beijing 100191, China

\section{References}

1. M'Koma AE. Inflammatory Bowel Disease: An Expanding Global Health Problem. Clinical Medicine Insights: Gastroenterology. 2013;6:CGast.S12731; doi:

10.4137

/CGast.S12731. https://doi.org/10.4137/CGast.S12731.

2. Rogler G. Interaction between Susceptibility and Environment: Examples from the Digestive Tract. Digestive Diseases. 2011;29 2:136-43; doi: 10.1159/000323876. https://www.karger.com/DOI/10.1159/000323876.

3. Ruiz PA, Morón B, Becker HM, Lang S, Atrott K, Spalinger MR, et al. Titanium dioxide nanoparticles exacerbate DSS-induced colitis: role of the NLRP3 inflammasome. Gut. 2017;66 7:1216; doi: 
10.1136/gutjnl-2015-310297. http://gut.bmj.com/content/66/7/1216.abstract.

4. Medina-Reyes El, Delgado-Buenrostro NL, Díaz-Urbina D, Rodríguez-lbarra C, Déciga-Alcaraz A, González Ml, et al. Food-grade titanium dioxide (E171) induces anxiety, adenomas in colon and goblet cells hyperplasia in a regular diet model and microvesicular steatosis in a high fat diet model. Food and Chemical Toxicology. 2020;146:111786; doi: https://doi.org/10.1016/j.fct.2020.111786.

5. Tian T, Wang Z, Zhang J. Pathomechanisms of Oxidative Stress in Inflammatory Bowel Disease and Potential Antioxidant Therapies. Oxid Med Cell Longev. 2017;2017:4535194-; doi:

10.1155/2017/4535194. https://pubmed.ncbi.nlm.nih.gov/28744337

6. Piechota-Polanczyk A, Fichna J. Review article: the role of oxidative stress in pathogenesis and treatment of inflammatory bowel diseases. Naunyn Schmiedebergs Arch Pharmacol. 2014;387 7:605-20; doi: 10.1007/s00210-014-0985-1. https://pubmed.ncbi.nlm.nih.gov/24798211

7. Chen Z, Zhou D, Han S, Zhou S, Jia G. Hepatotoxicity and the role of the gut-liver axis in rats after oral administration of titanium dioxide nanoparticles. Particle and Fibre Toxicology. 2019;16 1:48; doi: 10.1186/s12989-019-0332-2. https://doi.org/10.1186/s12989-019-0332-2.

8. Mu W, Wang Y, Huang C, Fu Y, Li J, Wang H, et al. Effect of Long-Term Intake of Dietary Titanium Dioxide Nanoparticles on Intestine Inflammation in Mice. Journal of Agricultural and Food Chemistry. 2019;67 33:9382-9; doi: 10.1021/acs.jafc.9b02391. https://doi.org/10.1021/acs.jafc.9b02391.

9. Chen X-X, Cheng B, Yang Y-X, Cao A, Liu J-H, Du L-J, et al. Characterization and Preliminary Toxicity Assay of Nano-Titanium Dioxide Additive in Sugar-Coated Chewing Gum. Small. 2013;9 9-10:176574; doi: https://doi.org/10.1002/smll.201201506. https://doi.org/10.1002/smll.201201506.

10. Yang Y, Doudrick K, Bi X, Hristovski K, Herckes P, Westerhoff P, et al. Characterization of Food-Grade Titanium Dioxide: The Presence of Nanosized Particles. Environmental Science \& Technology. 2014;48 11:6391-400; doi: 10.1021/es500436x. https://doi.org/10.1021/es500436x.

11. Rompelberg C, Heringa MB, van Donkersgoed G, Drijvers J, Roos A, Westenbrink S, et al. Oral intake of added titanium dioxide and its nanofraction from food products, food supplements and toothpaste by the Dutch population. Nanotoxicology. 2016;10 10:1404-14; doi: 10.1080/17435390.2016.1222457. https://doi.org/10.1080/17435390.2016.1222457.

12. Weir A, Westerhoff P, Fabricius L, Hristovski K, von Goetz N. Titanium Dioxide Nanoparticles in Food and Personal Care Products. Environmental Science \& Technology. 2012;46 4:2242-50; doi: 10.1021/es204168d. https://doi.org/10.1021/es204168d.

13. Shi H, Magaye R, Castranova V, Zhao J. Titanium dioxide nanoparticles: a review of current toxicological data. Particle and fibre toxicology. 2013;10:15-; doi: 10.1186/1743-8977-10-15. https://pubmed.ncbi.nlm.nih.gov/23587290.

14. Wang Y, Chen Z, Ba T, Pu J, Chen T, Song Y, et al. Susceptibility of Young and Adult Rats to the Oral Toxicity of Titanium Dioxide Nanoparticles. Small. 2013;9 9-10:1742-52; doi: https://doi.org/10.1002/smll.201201185. https://doi.org/10.1002/smll.201201185.

15. Chen Z, Wang Y, Zhuo L, Chen S, Zhao L, Chen T, et al. Interaction of titanium dioxide nanoparticles with glucose on young rats after oral administration. Nanomedicine: Nanotechnology, Biology and 
Medicine. 2015;11 7:1633-42; doi: https://doi.org/10.1016/j.nano.2015.06.002.

16. Gao Y, Ye Y, Wang J, Zhang H, Wu Y, Wang Y, et al. Effects of titanium dioxide nanoparticles on nutrient absorption and metabolism in rats: distinguishing the susceptibility of amino acids, metal elements, and glucose. Nanotoxicology. 2020;14 10:1301-23; doi: 10.1080/17435390.2020.1817597. https://doi.org/10.1080/17435390.2020.1817597.

17. Nogueira CM, de Azevedo WM, Dagli MLZ, Toma SH, Leite AZdA, Lordello ML, et al. Titanium dioxide induced inflammation in the small intestine. World J Gastroenterol. 2012;18 34:4729-35; doi: 10.3748/wjg.v18.i34.4729. https://pubmed.ncbi.nlm.nih.gov/23002342

18. Chen Z, Han S, Zhou D, Zhou S, Jia G. Effects of oral exposure to titanium dioxide nanoparticles on gut microbiota and gut-associated metabolism in vivo. Nanoscale. 2019;11 46:22398-412; doi: 10.1039/C9NR07580A. http://dx.doi.org/10.1039/C9NR07580A.

19. Li J, Yang S, Lei R, Gu W, Qin Y, Ma S, et al. Oral administration of rutile and anatase TiO2 nanoparticles shifts mouse gut microbiota structure. Nanoscale. 2018;10 16:7736-45; doi: 10.1039/C8NR00386F. http://dx.doi.org/10.1039/C8NR00386F.

20. Song Z-M, Chen N, Liu J-H, Tang H, Deng X, Xi W-S, et al. Biological effect of food additive titanium dioxide nanoparticles on intestine: an in vitro study. Journal of Applied Toxicology. 2015;35 10:1169-78; doi: https://doi.org/10.1002/jat.3171. https://doi.org/10.1002/jat.3171.

21. Setyawati MI, Tay CY, Leong DT. Mechanistic Investigation of the Biological Effects of SiO2, TiO2, and ZnO Nanoparticles on Intestinal Cells. Small. 2015;11 28:3458-68; doi: https://doi.org/10.1002/smll.201403232. https://doi.org/10.1002/smll.201403232.

22. Ammendolia MG, losi F, Maranghi F, Tassinari R, Cubadda F, Aureli F, et al. Short-term oral exposure to low doses of nano-sized TiO2 and potential modulatory effects on intestinal cells. Food Chem Toxicol. 2017;102:63-75; doi: 10.1016/j.fct.2017.01.031. https://doi.org/10.1016/j.fct.2017.01.031.

23. Bettini S, Boutet-Robinet E, Cartier C, Coméra C, Gaultier E, Dupuy J, et al. Food-grade TiO2 impairs intestinal and systemic immune homeostasis, initiates preneoplastic lesions and promotes aberrant crypt development in the rat colon. Scientific Reports. 2017;7 1:40373; doi: 10.1038/srep40373. https://doi.org/10.1038/srep40373.

24. Coyne JD. Crohn's disease with inflammatory splenic granuloma. J Clin Pathol. 2006;59 8:889; doi: 10.1136/jcp.2005.032508. https://pubmed.ncbi.nlm.nih.gov/16873574.

25. Corica D, Romano C. Renal Involvement in Inflammatory Bowel Diseases. Journal of Crohn's and Colitis. 2016;10 2:226-35; doi: 10.1093/ecco-jcc/jjv138. https://doi.org/10.1093/ecco-jcc/jjv138.

26. Zhang Y, Duan S, Liu Y, Wang Y. The combined effect of food additive titanium dioxide and lipopolysaccharide on mouse intestinal barrier function after chronic exposure of titanium dioxidecontained feedstuffs. Particle and Fibre Toxicology. 2021;18 1:8; doi: 10.1186/s12989-021-00399-x. https://doi.org/10.1186/s12989-021-00399-x.

27. Coates MD, Binion DG. Silent Inflammatory Bowel Disease. Crohn's \& Colitis 360. 2021;3 3; doi: 10.1093/crocol/otab059. https://doi.org/10.1093/crocol/otab059. 
28. Lu Y, Li X, Liu S, Zhang Y, Zhang D. Toll-like Receptors and Inflammatory Bowel Disease. Front Immunol. 2018;9:72; doi: 10.3389/fimmu.2018.00072. https://pubmed.ncbi.nlm.nih.gov/29441063.

29. Atreya I, Atreya R, Neurath MF. NF-kB in inflammatory bowel disease. Journal of Internal Medicine. 2008;263 6:591-6; doi: https://doi.org/10.1111/j.1365-2796.2008.01953.x. https://doi.org/10.1111/j.1365-2796.2008.01953.x.

30. Alzoghaibi MA. Concepts of oxidative stress and antioxidant defense in Crohn's disease. World J Gastroenterol. 2013;19 39:6540-7; doi: 10.3748/wjg.v19.i39.6540. https://pubmed.ncbi.nlm.nih.gov/24151379.

31. Manichanh C, Borruel N, Casellas F, Guarner F. The gut microbiota in IBD. Nature Reviews Gastroenterology \& Hepatology. 2012;9 10:599-608; doi: 10.1038/nrgastro.2012.152. https://doi.org/10.1038/nrgastro.2012.152.

32. Balmus IM, Ciobica A, Trifan A, Stanciu C. The implications of oxidative stress and antioxidant therapies in Inflammatory Bowel Disease: Clinical aspects and animal models. Saudi J Gastroenterol. 2016;22 1:3-17; doi: 10.4103/1319-3767.173753. https://pubmed.ncbi.nlm.nih.gov/26831601.

33. Lagkouvardos I, Lesker TR, Hitch TCA, Gálvez EJC, Smit N, Neuhaus K, et al. Sequence and cultivation study of Muribaculaceae reveals novel species, host preference, and functional potential of this yet undescribed family. Microbiome. 2019;7 1:28; doi: 10.1186/s40168-019-0637-2. https://doi.org/10.1186/s40168-019-0637-2.

34. Zazo H, Colino $\mathrm{Cl}$, Lanao JM. Current applications of nanoparticles in infectious diseases. Journal of Controlled Release. 2016;224:86-102; doi: https://doi.org/10.1016/j.jconrel.2016.01.008.

35. Wang L, Hu C, Shao L. The antimicrobial activity of nanoparticles: present situation and prospects for the future. Int J Nanomedicine. 2017;12:1227-49; doi: 10.2147/IJN.S121956. https://pubmed.ncbi.nlm.nih.gov/28243086.

36. Forman HJ, Zhang H, Rinna A. Glutathione: overview of its protective roles, measurement, and biosynthesis. Mol Aspects Med. 2009;30 1-2:1-12; doi: 10.1016/j.mam.2008.08.006. https://pubmed.ncbi.nlm.nih.gov/18796312.

37. Nimse SB, Pal D. Free radicals, natural antioxidants, and their reaction mechanisms. RSC Advances. 2015;5 35:27986-8006; doi: 10.1039/C4RA13315C. http://dx.doi.org/10.1039/C4RA13315C.

38. Jiang Q. Natural forms of vitamin E: metabolism, antioxidant, and anti-inflammatory activities and their role in disease prevention and therapy. Free Radic Biol Med. 2014;72:76-90; doi: 10.1016/j.freeradbiomed.2014.03.035. https://pubmed.ncbi.nlm.nih.gov/24704972.

39. Takami H, Taniguchi T, Moriya Y, Kuwahara T, Kanehisa M, Goto S. Evaluation method for the potential functionome harbored in the genome and metagenome. BMC Genomics. 2012;13 1:699; doi: 10.1186/1471-2164-13-699. https://doi.org/10.1186/1471-2164-13-699.

40. Zhou Y, Chen H, He H, Du Y, Hu J, Li Y, et al. Increased Enterococcus faecalis infection is associated with clinically active Crohn disease. Medicine (Baltimore). 2016;95 39:e5019; doi: 10.1097/MD.0000000000005019. https://pubmed.ncbi.nlm.nih.gov/27684872. 
41. Dethlefsen L, Huse S, Sogin ML, Relman DA. The Pervasive Effects of an Antibiotic on the Human Gut Microbiota, as Revealed by Deep 16S rRNA Sequencing. PLOS Biology. 2008;6 11:e280; doi: 10.1371/journal.pbio.0060280. https://doi.org/10.1371/journal.pbio.0060280.

42. Steck N, Hoffmann M, Sava IG, Kim SC, Hahne H, Tonkonogy SL, et al. Enterococcus faecalis Metalloprotease Compromises Epithelial Barrier and Contributes to Intestinal Inflammation. Gastroenterology. 2011;141 3:959-71; doi: https://doi.org/10.1053/j.gastro.2011.05.035.

43. Seishima J, lida N, Kitamura K, Yutani M, Wang Z, Seki A, et al. Gut-derived Enterococcus faecium from ulcerative colitis patients promotes colitis in a genetically susceptible mouse host. Genome Biology. 2019;20 1:252; doi: 10.1186/s13059-019-1879-9. https://doi.org/10.1186/s13059-019-18799.

44. Son HJ, Kim N, Song C-H, Nam RH, Choi SI, Kim JS, et al. Sex-related Alterations of Gut Microbiota in the C57BL/ 6 Mouse Model of Inflammatory Bowel Disease. J Cancer Prev. 2019;24 3:173-82; doi: 10.15430/JCP.2019.24.3.173.

45. Herp S, Brugiroux S, Garzetti D, Ring D, Jochum LM, Beutler M, et al. Mucispirillum schaedleri Antagonizes Salmonella Virulence to Protect Mice against Colitis. Cell Host \& Microbe. 2019;25 5:681-94.e8; doi: https://doi.org/10.1016/j.chom.2019.03.004.

46. Baumgart DC, Carding SR. Inflammatory bowel disease: cause and immunobiology. The Lancet. 2007;369 9573:1627-40; doi: https://doi.org/10.1016/S0140-6736(07)60750-8.

47. Hausmann M, Kiessling S, Mestermann S, Webb G, Spöttl T, Andus T, et al. Toll-like receptors 2 and 4 are up-regulated during intestinal inflammation. Gastroenterology. 2002;122 7:1987-2000; doi: 10.1053/gast.2002.33662. https://doi.org/10.1053/gast.2002.33662.

48. Marlow GJ, van Gent D, Ferguson LR. Why interleukin-10 supplementation does not work in Crohn's disease patients. World J Gastroenterol. 2013;19 25:3931-41; doi: 10.3748/wjg.v19.i25.3931. https://pubmed.ncbi.nlm.nih.gov/23840137

49. Liu T, Zhang L, Joo D, Sun S-C. NF-KB signaling in inflammation. Signal Transduction and Targeted Therapy. 2017;2 1:17023; doi: 10.1038/sigtrans.2017.23. https://doi.org/10.1038/sigtrans.2017.23.

50. Ip WKE, Hoshi N, Shouval DS, Snapper S, Medzhitov R. Anti-inflammatory effect of IL-10 mediated by metabolic reprogramming of macrophages. Science. 2017;356 6337:513-9; doi: 10.1126/science.aal3535. https://pubmed.ncbi.nlm.nih.gov/28473584

51. McNamara K, Tofail SAM. Nanoparticles in biomedical applications. Advances in Physics: X. 2017;2 1:54-88; doi: 10.1080/23746149.2016.1254570. https://doi.org/10.1080/23746149.2016.1254570.

52. Ziental D, Czarczynska-Goslinska B, Mlynarczyk DT, Glowacka-Sobotta A, Stanisz B, Goslinski T, et al. Titanium Dioxide Nanoparticles: Prospects and Applications in Medicine. Nanomaterials. 2020;10 2; doi: 10.3390/nano10020387.

53. Skocaj M, Filipic M, Petkovic J, Novak S. Titanium dioxide in our everyday life; is it safe? Radiology and Oncology. 2011;45 4:227-47; doi: doi:10.2478/v10019-011-0037-0. https://doi.org/10.2478/v10019-011-0037-0. 
54. Lubos E, Loscalzo J, Handy DE. Glutathione peroxidase-1 in health and disease: from molecular mechanisms to therapeutic opportunities. Antioxid Redox Signal. 2011;15 7:1957-97; doi: 10.1089/ars.2010.3586. https://pubmed.ncbi.nlm.nih.gov/21087145.

55. Reimund JM, Hirth C, Koehl C, Baumann R, Duclos B. Antioxidant and immune status in active Crohn's disease. A possible relationship. Clin Nutr. 2000;19 1:43-8; doi: 10.1054/clnu.1999.0073. https://doi.org/10.1054/clnu.1999.0073.

56. Liang G, Pu Y, Yin L, Liu R, Ye B, Su Y, et al. Influence of Different Sizes of Titanium Dioxide Nanoparticles on Hepatic and Renal Functions in Rats with Correlation to Oxidative Stress. Journal of Toxicology and Environmental Health, Part A. 2009;72 11-12:740-5; doi: 10.1080/15287390902841516. https://doi.org/10.1080/15287390902841516.

57. Nazıroğlu M, Muhamad S, Pecze L. Nanoparticles as potential clinical therapeutic agents in Alzheimer's disease: focus on selenium nanoparticles. Expert Review of Clinical Pharmacology. 2017;10 7:773-82; doi: 10.1080/17512433.2017.1324781. https://doi.org/10.1080/17512433.2017.1324781.

58. Li Q, Sanlioglu S, Li S, Ritchie T, Oberley L, Engelhardt JF. GPx-1 Gene Delivery Modulates NFkB Activation Following Diverse Environmental Injuries Through a Specific Subunit of the IKK Complex. Antioxid Redox Signal. 2001;3 3:415-32; doi: 10.1089/15230860152409068. https://doi.org/10.1089/15230860152409068.

59. Mendieta Zerón H, Flores A, Amaya A, Domínguez -García M. Oxidative stress in preeclampsia, more than enzymes. Revista Latinoamericana de Hipertension. 2013;8:25-8.

60. Zhang X, Ning Z, Mayne J, Yang Y, Deeke SA, Walker K, et al. Widespread protein lysine acetylation in gut microbiome and its alterations in patients with Crohn's disease. Nature Communications. 2020;11 1:4120; doi: 10.1038/s41467-020-17916-9. https://doi.org/10.1038/s41467-020-17916-9.

61. Longo S, Chieppa M, Cossa LG, Spinelli CC, Greco M, Maffia M, et al. New Insights into Inflammatory Bowel Diseases from Proteomic and Lipidomic Studies. Proteomes. 2020;8 3:18; doi: 10.3390/proteomes8030018. https://pubmed.ncbi.nlm.nih.gov/32784952

62. Park E-J, Yoon J, Choi K, Yi J, Park K. Induction of chronic inflammation in mice treated with titanium dioxide nanoparticles by intratracheal instillation. Toxicology. 2009;260 1-3:37-46; doi: 10.1016/j.tox.2009.03.005. https://doi.org/10.1016/j.tox.2009.03.005.

63. Hong J, Wang L, Zhao X, Yu X, Sheng L, Xu B, et al. Th2 Factors May Be Involved in TiO2 NP-Induced Hepatic Inflammation. Journal of Agricultural and Food Chemistry. 2014;62 28:6871-8; doi: 10.1021/jf501428w. https://doi.org/10.1021/jf501428w.

64. Sun L, He C, Nair L, Yeung J, Egwuagu CE. Interleukin 12 (IL-12) family cytokines: Role in immune pathogenesis and treatment of CNS autoimmune disease. Cytokine. 2015;75 2:249-55; doi: 10.1016/j.cyto.2015.01.030. https://pubmed.ncbi.nlm.nih.gov/25796985.

65. Gao Y, Li T, Duan S, Lyu L, Li Y, Xu L, et al. Impact of titanium dioxide nanoparticles on intestinal community in 2,4,6-trinitrobenzenesulfonic acid (TNBS)-induced acute colitis mice and the 
intervention effect of vitamin E. Nanoscale. 2021;13 3:1842-62; doi: 10.1039/DONR08106J. http://dx.doi.org/10.1039/D0NR08106J.

66. Wirtz S, Popp V, Kindermann M, Gerlach K, Weigmann B, Fichtner-Feigl S, et al. Chemically induced mouse models of acute and chronic intestinal inflammation. Nature Protocols. 2017;12 7:1295-309; doi: 10.1038/nprot.2017.044. https://doi.org/10.1038/nprot.2017.044.

67. Luk HH, Ko JKS, Fung HS, Cho $\mathrm{CH}$. Delineation of the protective action of zinc sulfate on ulcerative colitis in rats. European Journal of Pharmacology. 2002;443 1:197-204; doi: https://doi.org/10.1016/S0014-2999(02)01592-3.

\section{Tables}

Table 1. Organ weight coefficients of mice in different groups. (\%, mean $\pm S D, n=9)$

\begin{tabular}{|c|c|c|c|c|c|c|}
\hline \multirow[t]{2}{*}{ Group } & \multirow[t]{2}{*}{ liver } & \multirow[t]{2}{*}{ spleen } & \multicolumn{3}{|l|}{ kidney } & \multirow{2}{*}{$\begin{array}{l}\text { small } \\
\text { intestine } \\
\text { (jejunum + } \\
\text { ileum) }\end{array}$} \\
\hline & & & left & right & total & \\
\hline CT & $\begin{array}{l}5.02 \pm \\
0.27^{a}\end{array}$ & $\begin{array}{l}0.35 \pm \\
0.05^{a}\end{array}$ & $\begin{array}{l}0.76 \pm 0.06 \\
a b\end{array}$ & $\begin{array}{l}0.80 \pm \\
0.05^{a}\end{array}$ & $\begin{array}{l}1.56 \pm \\
0.11^{a}\end{array}$ & $6.79 \pm 1.13^{a}$ \\
\hline $\mathrm{TiO}_{2}$ & $\begin{array}{l}4.67 \pm \\
0.35^{a}\end{array}$ & $\begin{array}{l}0.37 \pm \\
0.12^{a}\end{array}$ & $\begin{array}{l}0.78 \pm 0.06 \\
a b\end{array}$ & $\begin{array}{l}0.80 \pm \\
0.06^{a}\end{array}$ & $\begin{array}{l}1.58 \pm \\
0.11^{a}\end{array}$ & $7.32 \pm 1.09^{a}$ \\
\hline TNBS & $\begin{array}{l}4.93 \pm \\
0.53^{a}\end{array}$ & $\begin{array}{l}0.42 \\
\pm 0.15^{\text {a }}\end{array}$ & $\begin{array}{l}0.86 \pm 0.07 \\
c\end{array}$ & $\begin{array}{l}0.93 \pm \\
0.07^{b}\end{array}$ & $\begin{array}{l}1.79 \pm \\
0.12 b c\end{array}$ & $8.15 \pm 0.66^{b}$ \\
\hline $\mathrm{TNBS}+\mathrm{TiO}_{2}$ & $\begin{array}{l}4.99 \pm \\
0.33^{a}\end{array}$ & $\begin{array}{l}0.41 \pm \\
0.05^{a}\end{array}$ & $\begin{array}{l}0.83 \pm 0.06 \\
b c\end{array}$ & $\begin{array}{l}0.85^{ \pm} \\
0.06^{a}\end{array}$ & $\begin{array}{l}1.69 \pm \\
0.12^{a c}\end{array}$ & $6.99 \pm 0.77^{a}$ \\
\hline TNBS+VE & $\begin{array}{l}4.54 \pm \\
0.34^{a}\end{array}$ & $\begin{array}{l}0.43 \pm \\
0.12^{a}\end{array}$ & $\begin{array}{l}0.77 \pm 0.04 \\
a b\end{array}$ & $\begin{array}{l}0.79 \pm \\
0.05^{a}\end{array}$ & $\begin{array}{l}1.57 \pm \\
0.08^{a}\end{array}$ & $6.93 \pm 0.86^{a}$ \\
\hline $\mathrm{TNBS}+\mathrm{TiO}_{2}+\mathrm{VE}$ & $\begin{array}{l}4.96 \pm \\
0.63^{a}\end{array}$ & $\begin{array}{l}0.34 \pm \\
0.11^{a}\end{array}$ & $\begin{array}{l}0.79 \pm 0.06 \\
a b c\end{array}$ & $\begin{array}{l}0.81 \pm \\
0.04^{a}\end{array}$ & $\begin{array}{l}1.60 \pm \\
0.10^{a}\end{array}$ & $7.02 \pm 0.56^{a}$ \\
\hline
\end{tabular}

Per organ weight coefficients in Groups that do not share any letter are significantly different according to a one-way ANOVA with LSD test $(p<0.05)$.

Table 2. Colon trait parameters of mice after $\mathrm{TiO}_{2}-\mathrm{NPs}$ and Vitamin $\mathrm{E}$ administration. (mean $\pm \mathrm{SD}$ ) 


\begin{tabular}{|c|c|c|c|c|c|c|}
\hline Group & $\begin{array}{l}\text { Colon } \\
\text { length } \\
\text { (cm) }\end{array}$ & $\begin{array}{l}\text { Colon } \\
\text { weight } \\
\text { (g) }\end{array}$ & $\begin{array}{l}\text { Colon organ } \\
\text { weight } \\
\text { coefficient } \\
(\%)\end{array}$ & $\begin{array}{l}\text { CMDI } \\
\text { score }\end{array}$ & $\begin{array}{l}\text { Histological } \\
\text { score }\end{array}$ & $\begin{array}{l}\text { Mucosal } \\
\text { height }(\mu \mathrm{m})\end{array}$ \\
\hline CT & $\begin{array}{l}7.98 \pm \\
0.41^{a}\end{array}$ & $\begin{array}{l}0.34 \pm \\
0.04^{a}\end{array}$ & $\begin{array}{l}1.27 \pm 0.12 \\
a b\end{array}$ & $\begin{array}{l}0.11 \pm \\
0.31^{\mathrm{a}}\end{array}$ & $\begin{array}{l}0.11 \pm 0.31 \\
\mathrm{a}\end{array}$ & $\begin{array}{l}104.1 \pm 3.3 \\
\mathrm{a}\end{array}$ \\
\hline $\mathrm{TiO}_{2}$ & $\begin{array}{l}7.83^{ \pm} \\
0.45^{\mathrm{a}}\end{array}$ & $\begin{array}{l}0.31 \pm \\
0.02^{a}\end{array}$ & $1.21 \pm 0.12^{a}$ & $\begin{array}{l}0.75 \pm \\
0.46^{\mathrm{ab}}\end{array}$ & $\begin{array}{l}0.33 \pm 0.47 \\
a\end{array}$ & $\begin{array}{l}104.7 \pm 1.7 \\
\mathrm{a}\end{array}$ \\
\hline TNBS & $\begin{array}{l}6.22 \pm \\
0.33^{b}\end{array}$ & $\begin{array}{l}0.31 \pm \\
0.05^{a}\end{array}$ & $\begin{array}{l}1.33 \pm 0.17 \\
a b\end{array}$ & $\begin{array}{l}4.50 \pm \\
1.97^{c}\end{array}$ & $\begin{array}{l}3.33 \pm 1.24 \\
b c\end{array}$ & $\begin{array}{l}131.6 \pm \\
32.0 \mathrm{bc}\end{array}$ \\
\hline $\mathrm{TNBS}+\mathrm{TiO}_{2}$ & $\begin{array}{l}6.79 \pm \\
0.50^{c}\end{array}$ & $\begin{array}{l}0.35 \pm \\
0.03^{a}\end{array}$ & $\begin{array}{l}1.42 \pm 0.13 \\
b c\end{array}$ & $\begin{array}{l}3.71 \pm \\
1.49 \mathrm{~d}\end{array}$ & $\begin{array}{l}4.75 \pm 2.16 \\
c\end{array}$ & $\begin{array}{l}143.9 \pm \\
23.0^{\mathrm{b}}\end{array}$ \\
\hline TNBS+VE & $\begin{array}{l}6.93 \pm \\
0.55^{\mathrm{cd}}\end{array}$ & $\begin{array}{l}0.30 \pm \\
0.06^{a}\end{array}$ & $\begin{array}{l}1.25 \pm 0.15 \\
a b\end{array}$ & $\begin{array}{l}2.42 \pm \\
0.98 \mathrm{bd}\end{array}$ & $\begin{array}{l}2.00 \pm 1.03 \\
a b c\end{array}$ & $\begin{array}{l}112.2 \pm \\
11.1 \mathrm{ac}\end{array}$ \\
\hline $\mathrm{TNBS}+\mathrm{TiO}_{2}+\mathrm{VE}$ & $\begin{array}{l}7.36 \pm \\
0.36^{d}\end{array}$ & $\begin{array}{l}0.34 \pm \\
0.06^{a}\end{array}$ & $\begin{array}{l}1.43 \pm 0.27 \\
b c\end{array}$ & $\begin{array}{l}2.55 \pm \\
1.39 \mathrm{~d}\end{array}$ & $\begin{array}{l}1.67 \pm 1.69 \\
a b\end{array}$ & $95.2 \pm 6.5^{a}$ \\
\hline
\end{tabular}

Per colon parameters in Groups that do not share any letter are significantly different according to a oneway ANOVA with LSD test or Mann-Whitney U test $(p<0.05)$. For colon length, weight, organ weight coefficient and CMDI score, nice samples are selected and analyzed in every group $(n=9)$, and for histological score and mucosal height, three samples are selected and analyzed in every group $(n=3)$.

Table 3. Cytokine content of mice after $\mathrm{TiO}_{2}$-NPs and Vitamin E administration. (mean $\pm \mathrm{SD}, \mathrm{n}=6$ )

\begin{tabular}{lllll} 
Group & Colon & \multicolumn{3}{l}{ Serum } \\
\cline { 2 - 5 } & TNF-a $(\mathrm{ng} / \mathrm{mgpro})$ & $\mathrm{IL}-12(\mathrm{ng} / \mathrm{mgpro})$ & TNF-a $(\mathrm{ng} / \mathrm{L})$ & $\mathrm{IL}-12(\mathrm{ng} / \mathrm{L})$ \\
\hline $\mathrm{CT}$ & $68.1 \pm 41.2^{\mathrm{abc}}$ & $1098.2 \pm 547.8^{\mathrm{a}}$ & $36.3 \pm 21.3^{\mathrm{a}}$ & $129.9 \pm 31.5^{\mathrm{a}}$ \\
\hline $\mathrm{TiO}_{2}$ & $107.2 \pm 54.2^{\mathrm{a}}$ & $517.2 \pm 26.4^{\mathrm{a}}$ & $37.1 \pm 21.9^{\mathrm{a}}$ & $183.3 \pm 63.3^{\mathrm{bc}}$ \\
\hline TNBS & $216.0 \pm 74.8^{\mathrm{d}}$ & $505.7 \pm 218.0^{\mathrm{a}}$ & $28.8 \pm 19.7^{\mathrm{a}}$ & $109.8 \pm 34.7^{\mathrm{ab}}$ \\
\hline${\mathrm{TNBS}+\mathrm{TiO}_{2}}^{161.9 \pm 26.8^{\mathrm{abc}}}$ & $552.1 \pm 99.7^{\mathrm{a}}$ & $39.1 \pm 9.0^{\mathrm{a}}$ & $162.0 \pm 30.8^{\mathrm{abc}}$ \\
\hline TNBS+VE & $190.9 \pm 48.1^{\mathrm{ab}}$ & $582.3 \pm 88.7^{\mathrm{a}}$ & $25.1 \pm 10.4^{\mathrm{a}}$ & $248.9 \pm 60.8^{\mathrm{c}}$ \\
\hline TNBS+TiO $_{2}+\mathrm{VE}$ & $111.9 \pm 91.8^{\mathrm{c}}$ & $746.9 \pm 166.8^{\mathrm{a}}$ & $25.7 \pm 15.3^{\mathrm{a}}$ & $159.5 \pm 48.2^{\mathrm{abc}}$
\end{tabular}

Per cytokine content in Groups that do not share any letter are significantly different according to a oneway ANOVA with LSD test $(p<0.05)$. 
Table 4. Oxidative stress in mouse colon after $\mathrm{TiO}_{2}-\mathrm{NPs}$ and Vitamin $\mathrm{E}$ administration. (mean $\pm \mathrm{SD}, \mathrm{n}=6$ )

\begin{tabular}{|c|c|c|c|c|c|c|}
\hline Group & $\begin{array}{l}\text { ROS } \\
\text { (FI / } \\
10^{8} \\
\text { cells) }\end{array}$ & $\begin{array}{l}\text { GSH-px } \\
\text { vitality } \\
\text { (U/mgpro) }\end{array}$ & $\begin{array}{l}\text { GSH } \\
\text { ( } \mu \mathrm{mol} / \mathrm{mgpro})\end{array}$ & $\begin{array}{l}\text { GSSG } \\
\text { ( } \mu \mathrm{mol} / \mathrm{mgpro})\end{array}$ & $\begin{array}{l}\text { GSH / } \\
\text { GSSG }\end{array}$ & $\begin{array}{l}\text { T-GSH } \\
\text { ( } \mu \mathrm{mol} / \mathrm{mgpro})\end{array}$ \\
\hline CT & $\begin{array}{l}139.7 \\
\pm \\
92.0^{\mathrm{a}}\end{array}$ & $\begin{array}{l}71.0 \\
\pm 24.5^{\mathrm{a}}\end{array}$ & $96.9 \pm 83.9^{a}$ & $71.4 \pm 55.1^{a}$ & $\begin{array}{l}1.38 \\
\pm \\
1.12^{\mathrm{a}}\end{array}$ & $\begin{array}{l}239.8 \pm 182.9 \\
a\end{array}$ \\
\hline $\mathrm{TiO}_{2}$ & $\begin{array}{l}208.7 \\
\pm \\
205.8 \\
a b\end{array}$ & $\begin{array}{l}55.7 \pm \\
11.1^{\mathrm{b}}\end{array}$ & $34.5 \pm 28.9^{b}$ & $31.4 \pm 12.2^{b c}$ & $\begin{array}{l}1.10 \\
\pm \\
2.00 \\
a b\end{array}$ & $97.4 \pm 18.4 \mathrm{bc}$ \\
\hline TNBS & $\begin{array}{l}292.0 \\
\pm \\
121.2 \\
\text { bc }\end{array}$ & $\begin{array}{l}37.5 \pm 5.6 \\
c\end{array}$ & $14.3 \pm 11.0 \mathrm{bc}$ & $46.3 \pm 15.5^{a b}$ & $\begin{array}{l}0.40 \\
\pm \\
0.30 \\
\mathrm{bc}\end{array}$ & $106.7 \pm 24.3^{c}$ \\
\hline $\mathrm{TNBS}+\mathrm{TiO}_{2}$ & $\begin{array}{l}321.5 \\
\pm \\
140.5 \\
b\end{array}$ & $\begin{array}{l}40.9 \pm 7.9 \\
b c\end{array}$ & $-7.6 \pm 21.1^{d}$ & $38.9 \pm 18.6^{a c}$ & $\begin{array}{l}-0.19 \\
\pm \\
0.46 \\
\mathrm{bc}\end{array}$ & $70.3 \pm 21.2^{b}$ \\
\hline TNBS+VE & $\begin{array}{l}121.2 \\
\pm \\
69.9 \text { a }\end{array}$ & $\begin{array}{l}51.4 \pm 7.5 \\
\text { bc }\end{array}$ & $3.4 \pm 13.3^{\mathrm{bcd}}$ & $32.8 \pm 10.9 b c$ & $\begin{array}{l}0.10 \\
\pm \\
0.62 \\
\text { bc }\end{array}$ & $69.1 \pm 11.1^{b}$ \\
\hline $\mathrm{TNBS}+\mathrm{TiO}_{2}+\mathrm{VE}$ & $\begin{array}{l}163.4 \\
\pm \\
55.1^{a}\end{array}$ & $\begin{array}{l}43.2 \pm 3.3 \\
b c\end{array}$ & $2.1 \pm 8.7^{\mathrm{cd}}$ & $23.8 \pm 14.0^{c}$ & $\begin{array}{l}0.09 \\
\pm \\
0.68^{c}\end{array}$ & $49.8 \pm 25.9^{b}$ \\
\hline
\end{tabular}

Per oxidative stress parameters in Groups that do not share any letter are significantly different according to a one-way ANOVA with LSD test $(p<0.05)$.

FI: Fluorescence intensity.

Table 5. Oxidative stress in mouse serum after $\mathrm{TiO}_{2}$-NPs and Vitamin E administration. (mean $\pm \mathrm{SD}, \mathrm{n}=6$ ) 


\begin{tabular}{|c|c|c|c|c|c|}
\hline Group & $\begin{array}{l}\text { GSH-px vitality } \\
(\mathrm{U} / \mathrm{L})\end{array}$ & $\begin{array}{l}\mathrm{GSH} \\
(\mu \mathrm{mol} / \mathrm{L})\end{array}$ & $\begin{array}{l}\text { GSSG } \\
(\mu \mathrm{mol} / \mathrm{L})\end{array}$ & $\begin{array}{l}\text { GSH / } \\
\text { GSSG }\end{array}$ & $\begin{array}{l}\text { T-GSH } \\
(\mu \mathrm{mol} / \mathrm{L})\end{array}$ \\
\hline CT & $843.3 \pm 29.5^{a}$ & $12.9 \pm 3.2^{a}$ & $11.9 \pm 0.9^{a}$ & $\begin{array}{l}1.06 \pm \\
0.42^{a}\end{array}$ & $36.7 \pm 6.5^{\mathrm{a}}$ \\
\hline $\mathrm{TiO}_{2}$ & $884.4 \pm 70.4^{a}$ & $12.4 \pm 2.0^{a}$ & $8.9 \pm 3.9^{a}$ & $\begin{array}{l}1.39 \pm \\
1.40^{a}\end{array}$ & $30.2 \pm 8.6^{a}$ \\
\hline TNBS & $834.0 \pm 88.2^{a}$ & $10.8 \pm 2.3^{a}$ & $11.6 \pm 2.5^{a}$ & $\begin{array}{l}0.94 \pm \\
0.14^{a}\end{array}$ & $34.8 \pm 7.1^{a}$ \\
\hline $\mathrm{TNBS}+\mathrm{TiO}_{2}$ & $695.6 \pm 97.1^{c}$ & $12.1 \pm 5.3^{a}$ & $11.5 \pm 3.4^{a}$ & $\begin{array}{l}1.13^{ \pm} \\
0.55^{a}\end{array}$ & $35.1 \pm 7.5^{a}$ \\
\hline TNBS+VE & $807.2 \pm 68.1^{a}$ & $12.8 \pm 3.6^{a}$ & $13.2 \pm 2.8^{a}$ & $\begin{array}{l}0.98 \pm \\
0.13^{a}\end{array}$ & $39.3 \pm 8.1^{a}$ \\
\hline $\mathrm{TNBS}+\mathrm{TiO}_{2}+\mathrm{VE}$ & $810 \pm 32.7^{a}$ & $14.2 \pm 1.7^{a}$ & $13.4 \pm 3.9^{a}$ & $\begin{array}{l}1.20 \pm 0.59 \\
\mathrm{a}\end{array}$ & $40.9 \pm 8.9^{a}$ \\
\hline
\end{tabular}

Per oxidative stress parameters in Groups that do not share any letter are significantly different according to a one-way ANOVA with LSD test $(p<0.05)$.

Table 6. Microbiome a-diversity index of mice after $\mathrm{TiO}_{2}-\mathrm{NPs}$ and Vitamin $\mathrm{E}$ administration. (mean $\pm \mathrm{SD}$, $n=5)$

\begin{tabular}{|c|c|c|c|c|c|c|}
\hline Group & Observed_species & Shannon & Simpson & Chao1 & ACE & PD_whole_tree \\
\hline CT & $306.2 \pm 72.9 \mathrm{a}$ & $\begin{array}{l}4.83^{ \pm} \\
1.21^{\mathrm{a}}\end{array}$ & $\begin{array}{l}0.89 \pm \\
0.06^{a}\end{array}$ & $\begin{array}{l}329.7 \pm \\
61.7^{a}\end{array}$ & $\begin{array}{l}338.7 \pm \\
57.6^{a}\end{array}$ & $19.9 \pm 3.9^{a}$ \\
\hline $\mathrm{TiO}_{2}$ & $337.0 \pm 36.4^{a}$ & $\begin{array}{l}5.39 \pm \\
0.78^{a}\end{array}$ & $\begin{array}{l}0.92 \pm \\
0.05^{a}\end{array}$ & $\begin{array}{l}359.3 \pm \\
31.9 \mathrm{ab}\end{array}$ & $\begin{array}{l}364.3 \pm \\
31.9 \mathrm{ab}\end{array}$ & $21.6 \pm 2.0^{a}$ \\
\hline TNBS & $369.2 \pm 14.0^{a}$ & $\begin{array}{l}5.59 \pm \\
0.48^{a}\end{array}$ & $\begin{array}{l}0.94 \pm \\
0.03^{a}\end{array}$ & $\begin{array}{l}393.5^{ \pm} \\
20.8^{b}\end{array}$ & $\begin{array}{l}393.2 \pm \\
19.1^{b}\end{array}$ & $24.2 \pm 1.7^{\mathrm{a}}$ \\
\hline $\mathrm{TNBS}+\mathrm{TiO}_{2}$ & $328.2 \pm 26.6^{a}$ & $\begin{array}{l}5.32 \pm \\
1.04^{\mathrm{a}}\end{array}$ & $\begin{array}{l}0.93^{ \pm} \\
0.06^{a}\end{array}$ & $\begin{array}{l}342.1 \pm \\
31.4^{\mathrm{a}}\end{array}$ & $\begin{array}{l}347.7 \pm \\
33.3 \mathrm{ab}\end{array}$ & $23.2 \pm 2.1^{\mathrm{a}}$ \\
\hline TNBS+VE & $364.2 \pm 64.1^{a}$ & $\begin{array}{l}5.91 \pm \\
0.52^{a}\end{array}$ & $\begin{array}{l}0.96 \pm \\
0.02^{a}\end{array}$ & $\begin{array}{l}380.2 \pm \\
63.8 \mathrm{ab}\end{array}$ & $\begin{array}{l}386.6 \pm \\
61.6 \mathrm{ab}\end{array}$ & $22.7 \pm 2.8^{a}$ \\
\hline $\mathrm{TNBS}+\mathrm{TiO}_{2}+\mathrm{VE}$ & $332.0 \pm 28.8^{a}$ & $\begin{array}{l}5.34 \pm \\
0.99^{a}\end{array}$ & $\begin{array}{l}0.89 \pm \\
0.10^{a}\end{array}$ & $\begin{array}{l}349.9 \pm \\
28.5^{\mathrm{ab}}\end{array}$ & $\begin{array}{l}356.7 \pm \\
27.6 \mathrm{ab}\end{array}$ & $22.0 \pm 1.0^{a}$ \\
\hline
\end{tabular}

Per index in Groups that do not share any letter are significantly different according to Wilcoxon signedrank test $(p<0.05)$. 
Figures
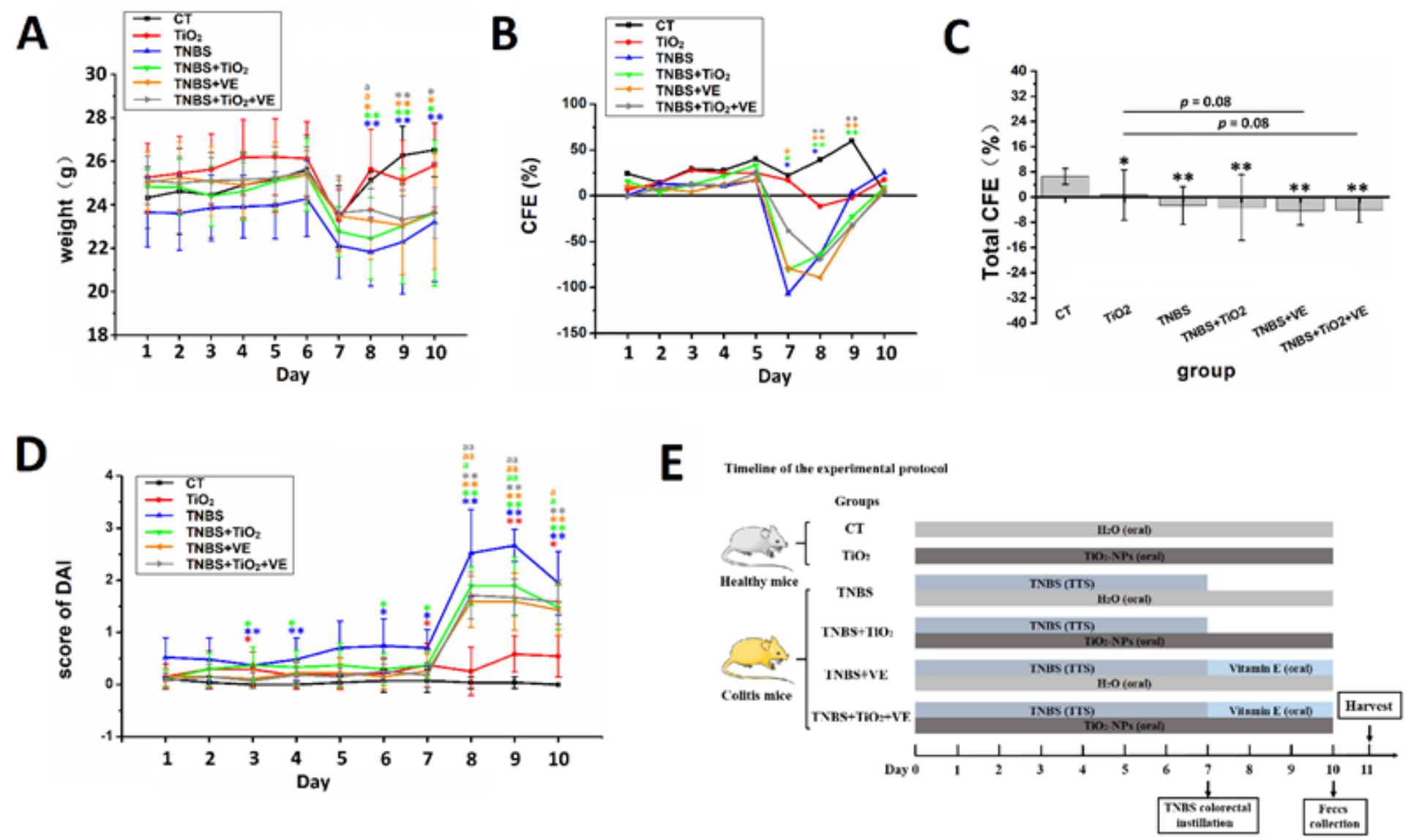

\section{Figure 1}

Effect of TiO2-NPs on TNBS-induced mice acute colitis. Body weight (A), coefficient of feeding efficiency $(\mathrm{CFE}, \%)(\mathrm{B})$, total CFE (C) and disease activity index (DAI) score (D) of animals after the TNBS-colitis inducement and TiO2-NPs or vitamin $E$ treatment $(n=9)$. For CFE, mice were fasted at Day 6 for the TNBS colorectal instillation, thus the CFE of mice at Day 6 was not included. Significant difference was found between the CT group and the experimental groups ( $* \star p<0.01, * p<0.05$ ). Significant difference was also found between the TNBS group and other experimental groups ( aa $p<0.01$, a $p<0.05$ ). E. Timeline of the experimental protocols, TTS was for the trandermal thrapeutic systems. 

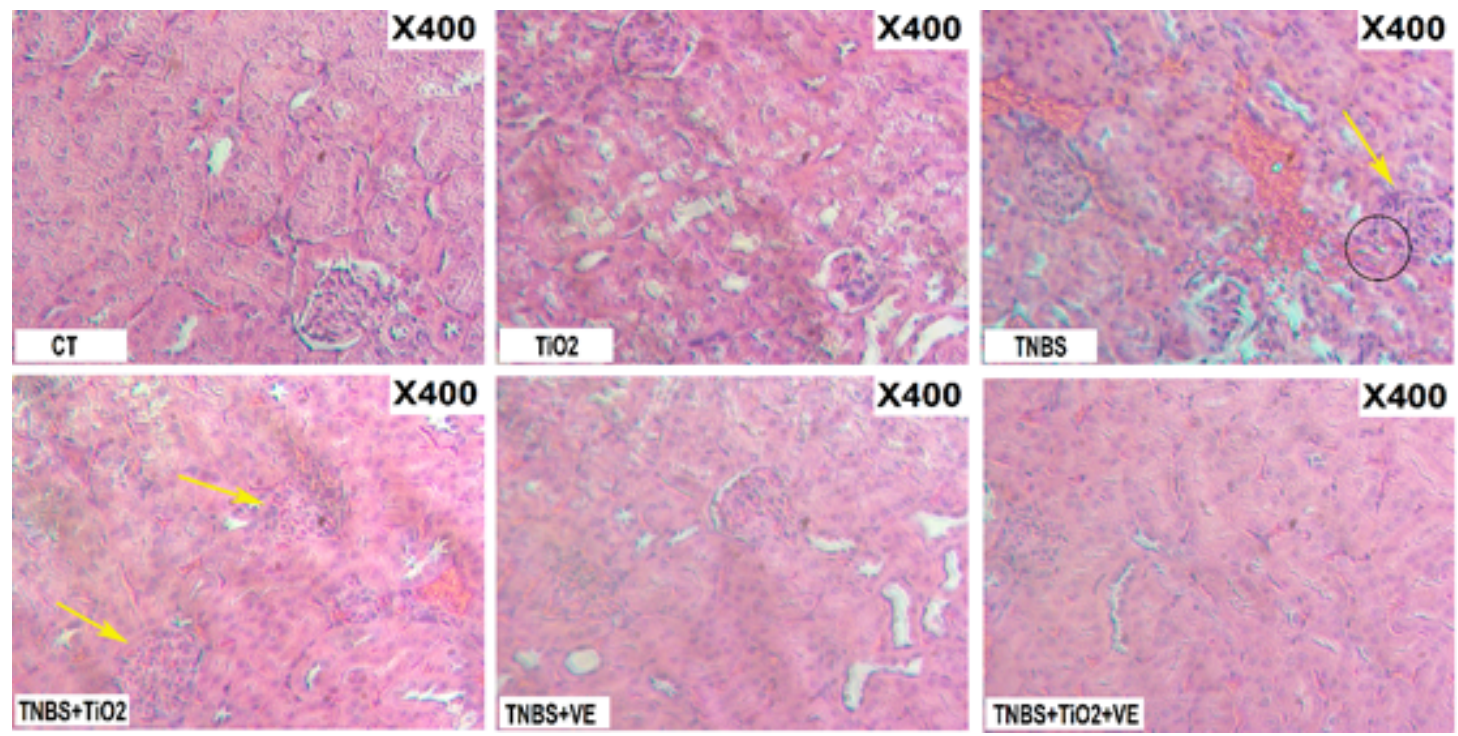

\section{Figure 2}

Representative histological photomicrographs of mouse left kidney after TiO2-NPs and Vitamin E administration $(n=3)$. Yellow arrows indicate glomerular hyperemia and Black circle indicates glomerular hemorrhage.
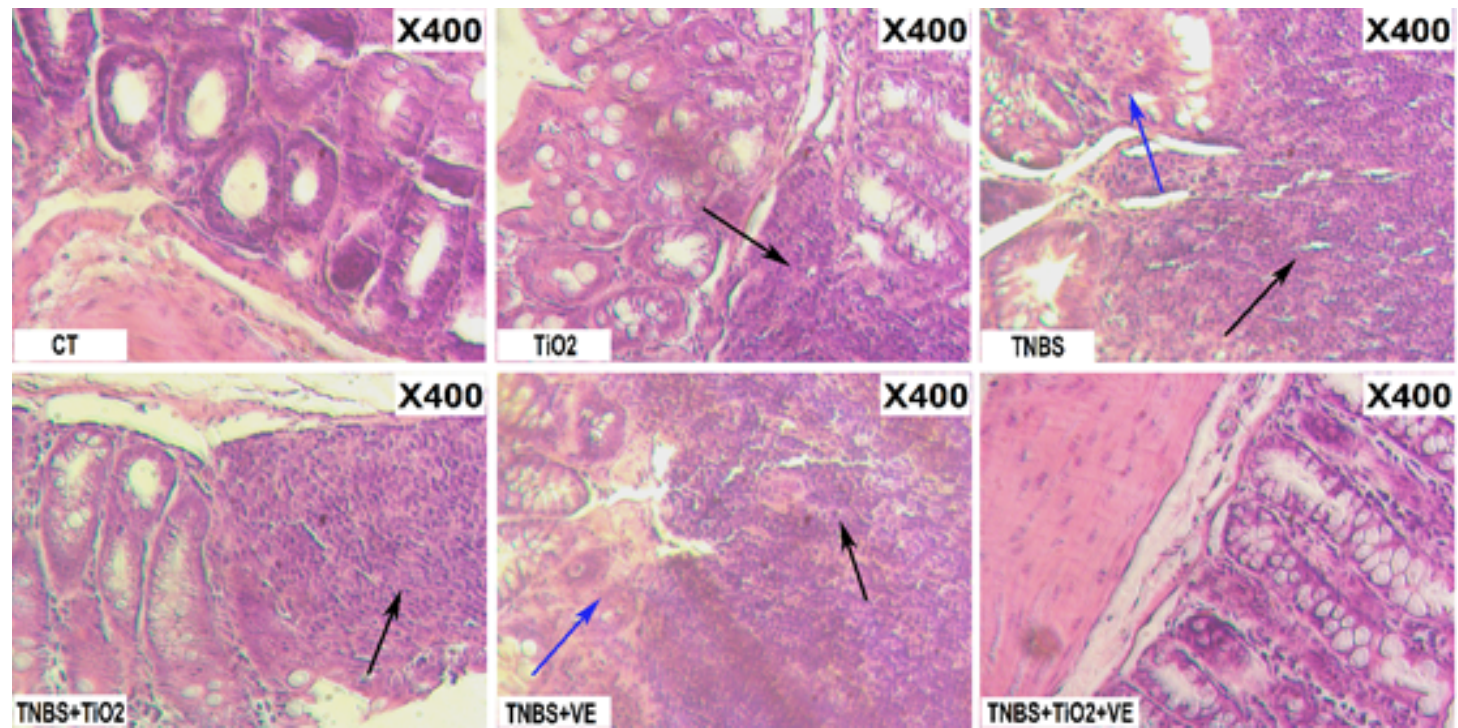

\section{Figure 3}

Representative histological photomicrographs of mouse colon after TiO2-NPs and Vitamin E administration $(n=3)$. Black arrows indicate inflammatory cell infiltration in the colonic epithelium, blue arrows indicate goblet cells and crypt structures were lost in TNBS and TNBS+VE group. 


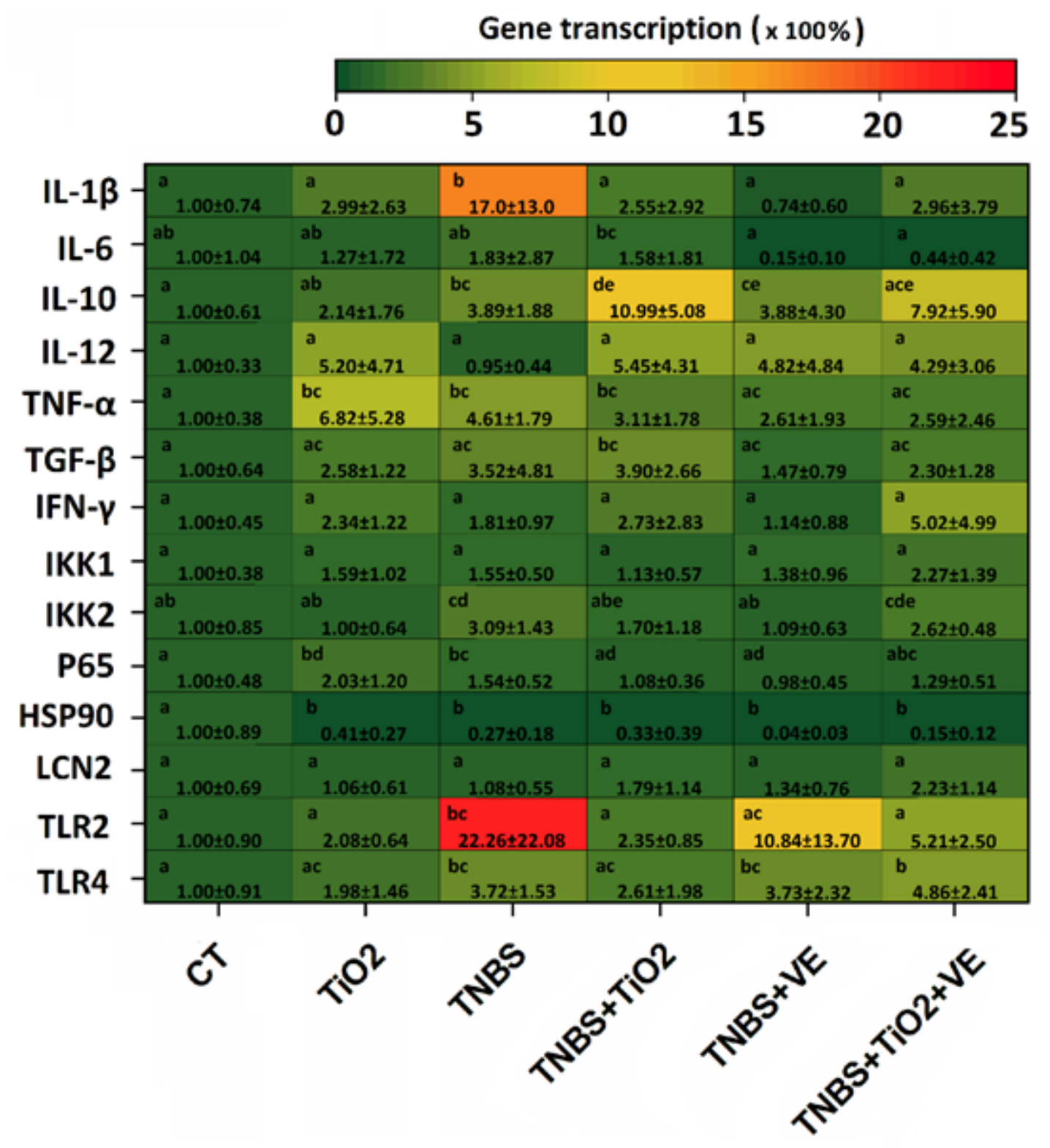

Figure 4

TiO2-NPs and Vitamin E administration changed gene transcription in colonic epithelium of mice $(n=6)$. Per gene, treatments groups that do not share any letter are significantly different according to a one-way ANOVA with LSD $(p<0.05)$. 
A

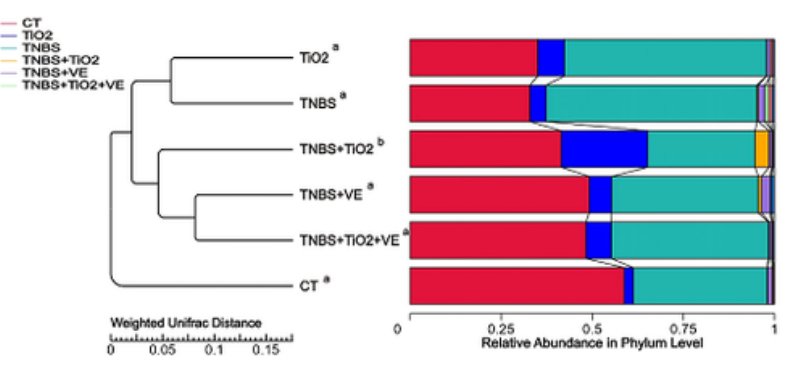

B

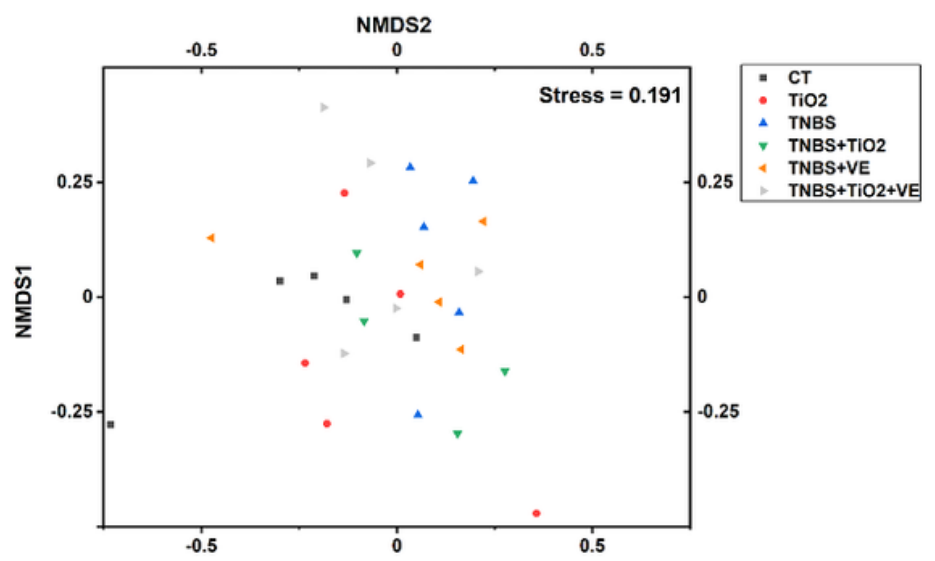

C

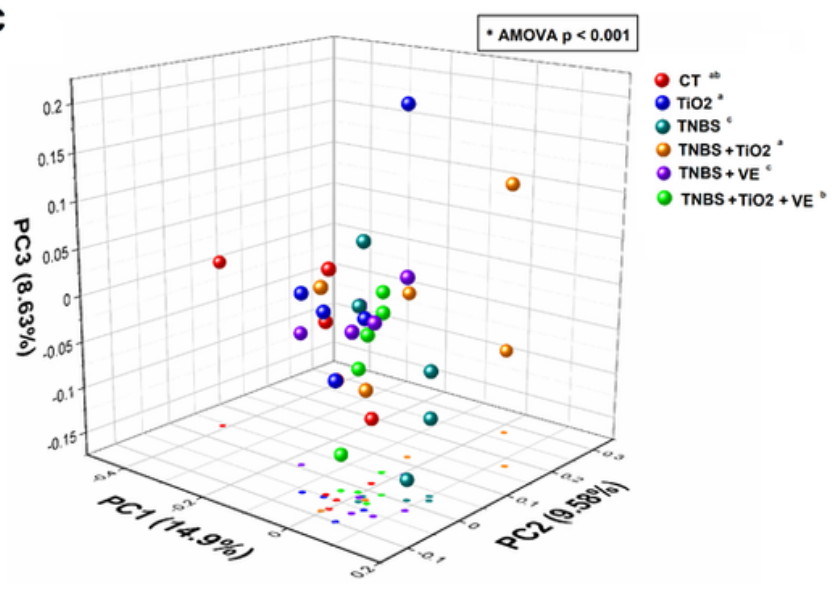

\section{Figure 5}

Microbiome beta-diversity changes of mouse stool samples after TiO2-NPs and Vitamin E administration $(n=5)$. (A) The weighted UniFrac distance and relative abundance in phylum level of microbiome, for UniFrac distance, groups that do not share any letter are significantly different according to Wilcoxon signed-rank test ( $\left.{ }^{*} p<0.05\right)$. (B) The NMDS map of microbiome. (C) Principal component analysis (PCA) of microbiome based on UniFrac distance, groups that do not share any letter are significantly different according to Analysis of molecular variance (AMOVA). 


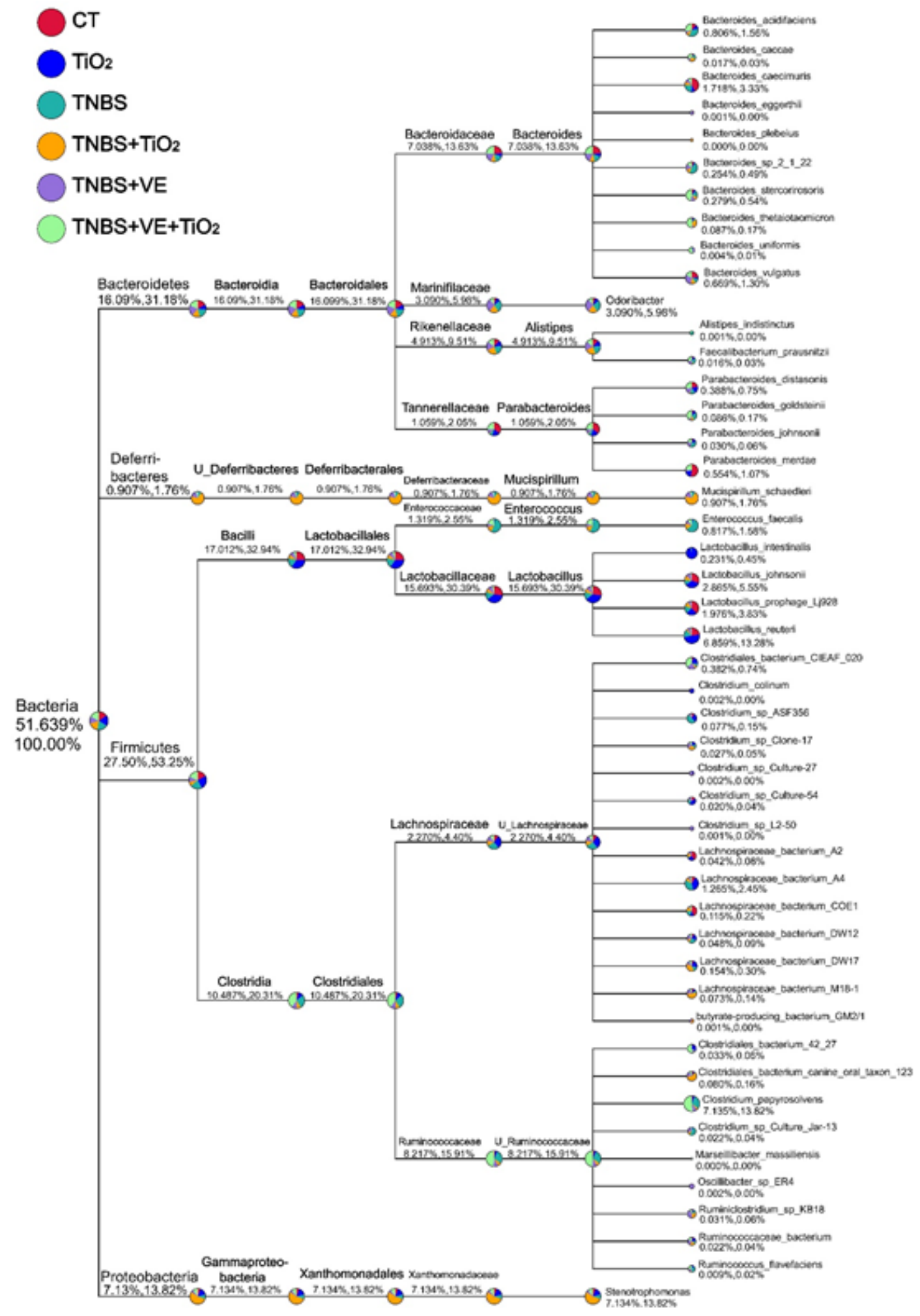

\section{Figure 6}

Specific species Taxtree analysis of microbiota in mice after TiO2-NPs and Vitamin E administration $(n=5)$. Classification levels include the kingdom, phylum, class, order, family, genus and species. The first percentile in parentheses showed the percentage of microflora in all detected bacteria. The second percentile in parentheses showed the percentage of microflora in all selected bacteria. 

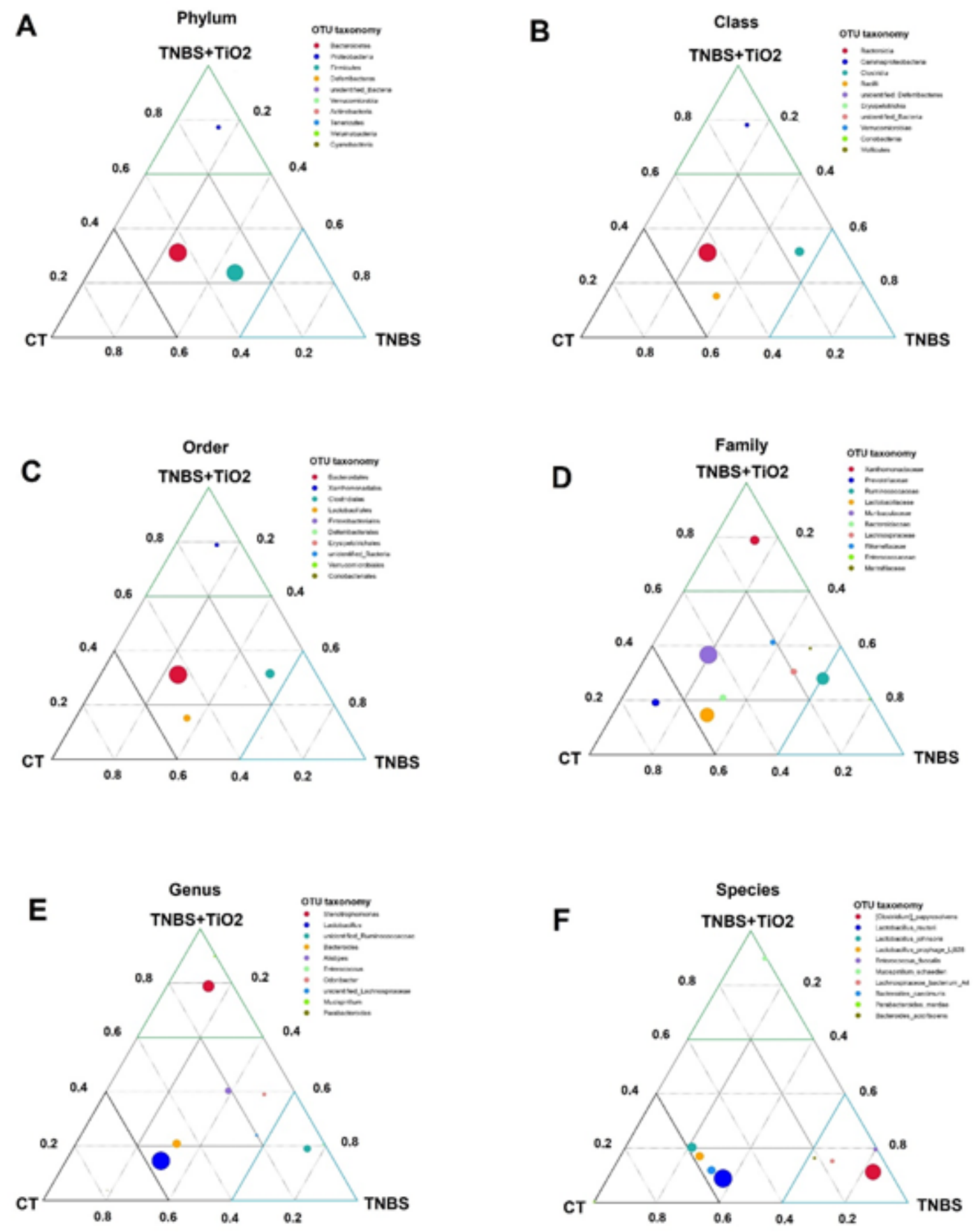

Figure 7

Specific species Taxtree analysis of microbiota in mice after TiO2-NPs and Vitamin E administration $(n=5)$. Classification levels include the kingdom, phylum, class, order, family, genus and species. The first percentile in parentheses showed the percentage of microflora in all detected bacteria. The second percentile in parentheses showed the percentage of microflora in all selected bacteria. 

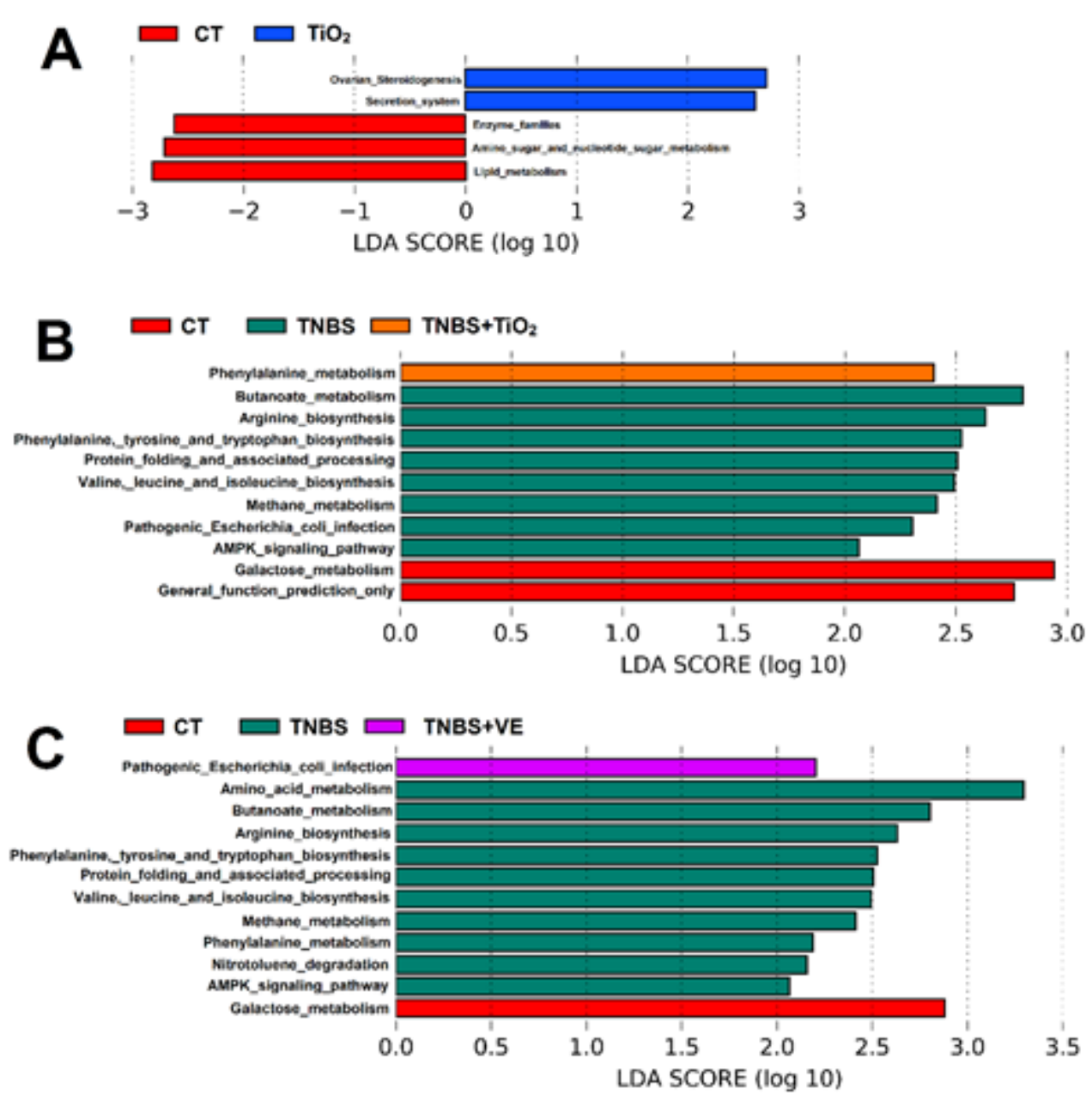

\section{Figure 8}

Differentially expressed microbiota related function in mice stool after TiO2-NPs and vitamin E treatment $(n=5)$. A: Bacterial function differentially expressed in the TiO2 group when compared with the CT group. B: Bacterial function differentially expressed in CT, TNBS and TNBS+TiO2 group when compared with each other. C: Bacterial function differentially expressed in CT, TNBS and TNBS+VE group when compared with each other. 


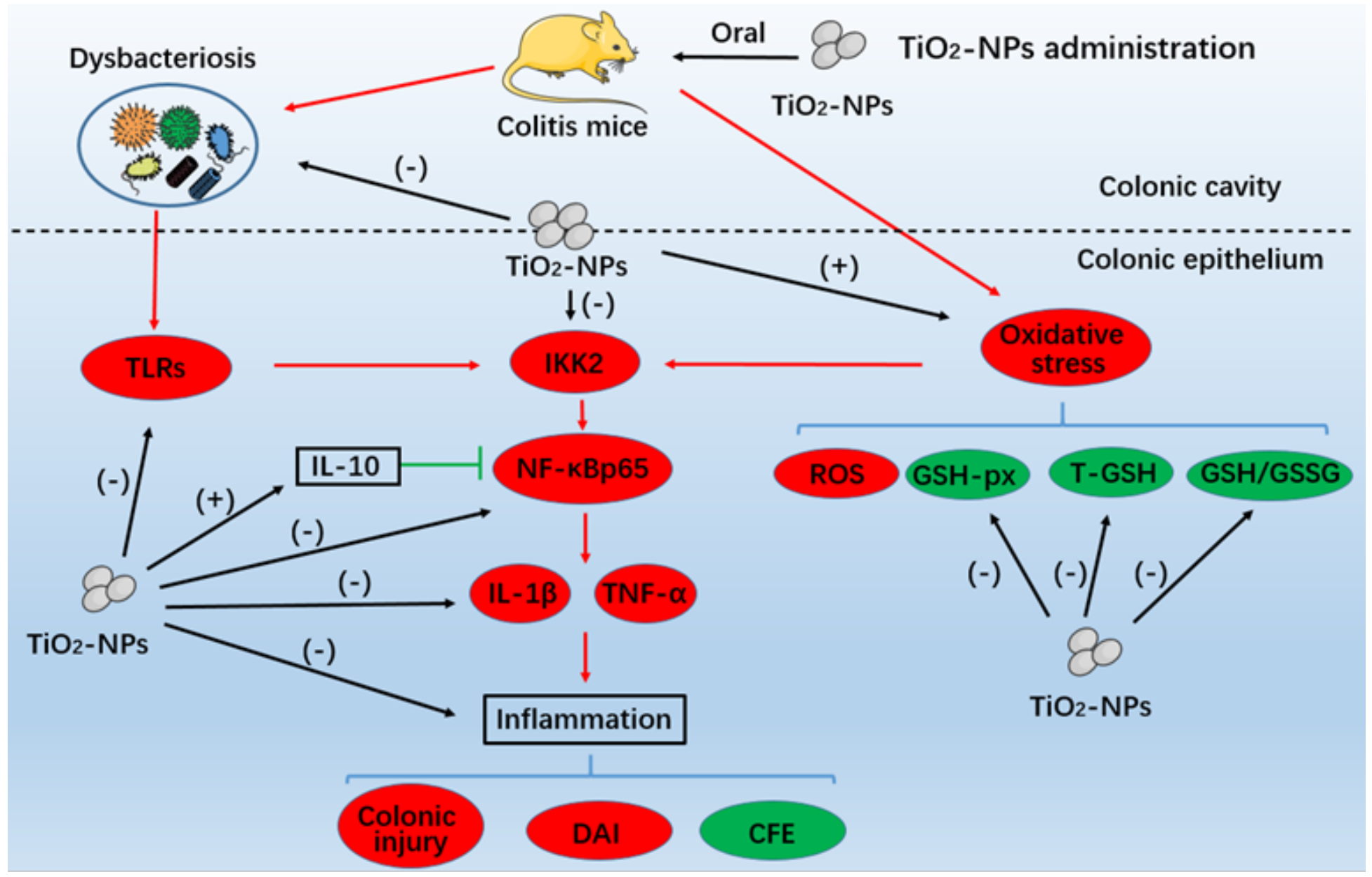

\section{Figure 9}

TiO2-NPs participated in colitis mitigation in colitis mice. Red arrows or circles indicated functional promotion or increased transcription and expression, green arrow arrows or circles indicated functional inhibition or decreased level of antioxidants during the colitis inducement. Black arrows with (+) indicated that TiO2-NPs triggered oxidative stress and increased IL-10 transcription, arrows with (-) indicated TiO2NPs repaired dysbacteriosis, decreased antioxidant content and downregulated inflammation related transcription and expression. 

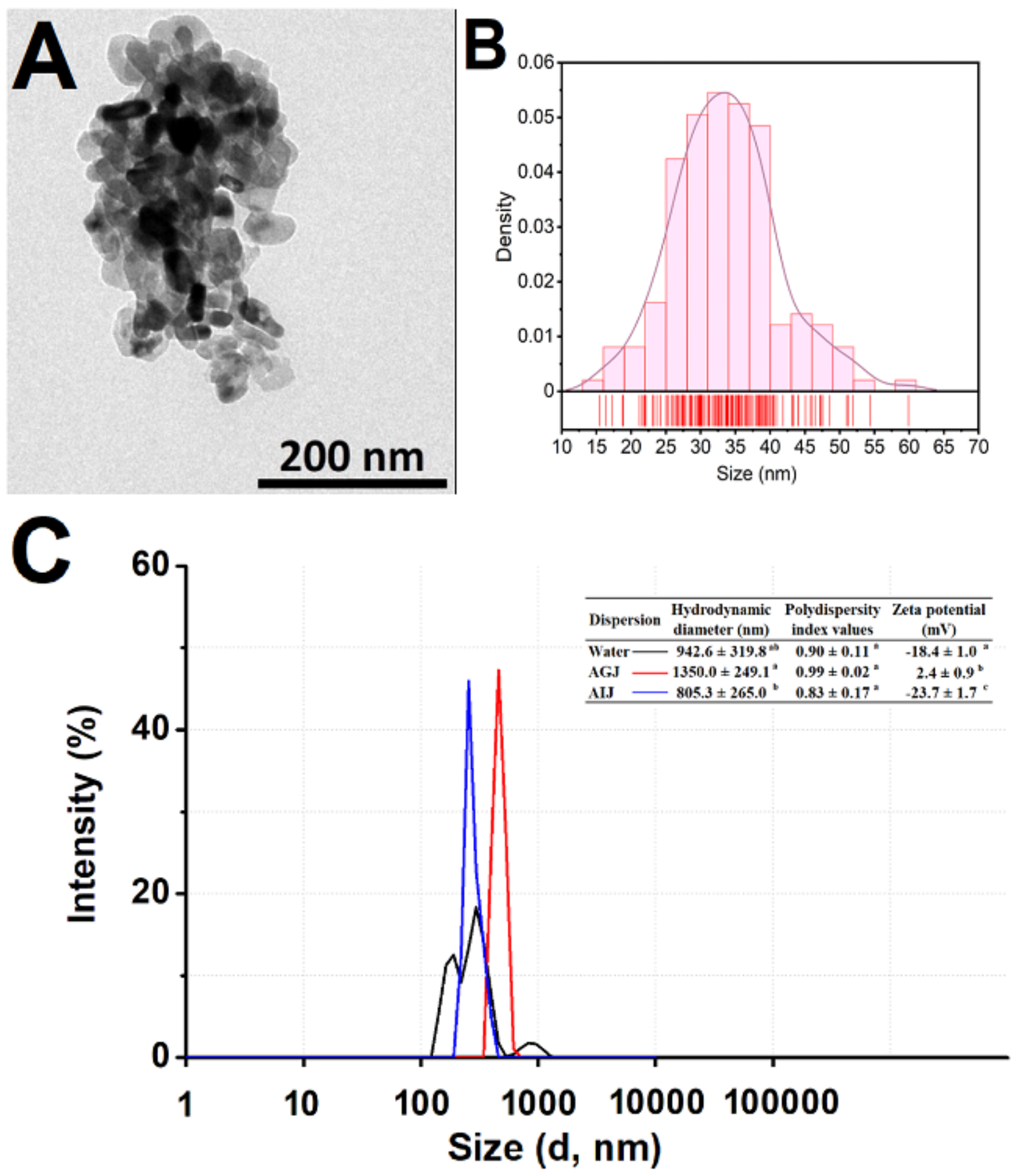

Figure 10

Characterization of TiO2-NPs. (A) The representative TEM image of TiO2-NPs, (B) TEM based size distributions of TiO2-NPs $(n=161)$ and $(C)$ hydrodynamic diameter distribution of TiO2-NPs in ultrapure water (H2O), artificial gastric juice (AGJ) and artificial intestinal juice (AIJ). For Hydrodynamic diameter, $\mathrm{PDI}$ and Zeta potential of TiO2-NPs, parameters in three dispersions that do not share any letter are significantly different $(p<0.05)$ according to a one-way ANOVA with LSD test (mean $\pm S D, n=3$ ). 


\section{Supplementary Files}

This is a list of supplementary files associated with this preprint. Click to download.

- AdditionalFile.mp4

- introductiontoAdditionalFile.docx 